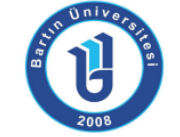

ISSN: 1308-7177

\title{
Üç Doğa Eğitim Projesinin Katılımcı Üzerindeki Etkilerinin Nicel ve Nitel Yoldan Değerlendirilmesi ${ }^{*}$
}

İdris OĞURLU, Prof. Dr., İstanbul Ticaret Üniversitesi, Çevre ve Doğa Bilimleri Uygulama ve Araştırma Merkezi, iogurlu@ticaret.edu.tr

Suat TÜRKOGUZ, Doç. Dr., Dokuz Eylül Üniversitesi, Buca Eğitim Fakültesi, Matematik ve Fen Bilimleri Eğitimi Bölümü, suat.turkoguz@gmail.com

Öz: Bu makalede çoğunluğu öğretmen 227 katııımının, 2007-2010 yılları arasında Isparta'nın milli park ve tabiat parkı gibi korunan doğal alanlarında (KDA) gerçekleşen 3 doğa eğitim projesine (URL1) katılmalarında rol oynayan temel faktörlerin ve katılımcıda eğitim sonunda oluşan değişikliklerin belirlenmesi amaçlanmıştır. Eğitimin ilk ve son günü yapılan anketler ile bir izleme anketine ait veriler nicel ve nitel araştırma yöntemleriyle değerlendirilmiştir. Öğretmenlerin katılım kararında en etkili faktörün doğa hakkında daha fazlasını öğrenmek ve öğrendiklerini öğrencileriyle paylaşmak olduğu tespit edilmiştir. İzleme anketleri aldıkları doğa eğitiminin, kendilerine, öğrencilerini eğitmede büyük imkânlar sağladığını ve mesleklerine önemli katkı sağladığının belirten katılımcıların IDE Projelerinde edindikleri müktesebatın meslek hayatlarında kayda değer yararlar sağladığını göstermiştir.

Anahtar Kelimeler: Doğa eğitimi, Isparta, KDA’lar, Nicel analiz, Nitel değerlendirme

\section{Qualitative and Quantitative Evaluation of Effects on Participants of the Three Nature Training Projects}

Abstract: Three Nature Training Projects (URL-1) were realized in NPA's in Isparta from 2007 to 2010 with 227 participants most of them teachers. In this study it was aimed to determine main factors had lead those teachers to participate in and changes arised at the end of the training. Interviews, on the first and the last day of the courses as well as follow up were conducted with the participants by using qualitative and quantitative methods. The factor most effective over the decisions for participating in were found learning more about Nature and sharing it with their students. They addressed that courses had supplied great facilities for training their students and considerable contribution in their career.

Key Words: Nature training, Isparta, NPA's, Qualitative analysis, Quantitative methods

\footnotetext{
* Bu makale "Isparta Korunan Doğal Alanlarında Doğa Eğitimi (IDE) adıyla bilinen TÜBiTAK'ın destek sağladığı üç ayrı proje olan IDE-1(proje no 107B031), IDE-2 (108B015) ve IDE-3 (110B089)'ün verilerine dayanmaktadır.
} 


\section{GíRiş}

Çevre sorunlarında problemin ana kaynağı ve çekirdek unsurun insan olduğu ortaya çıkınca, yapılacak öncelikli işin de insan davranışlarının değişmesini sağlamak olduğu iyice anlaşılmıştır (Doğan, 2007; Oğurlu, Alkan ve Gündoğdu, 2010). Bilindiği gibi, insan davranışları; bilişsel, duyuşsal ve devinimsel alanları kapsar. Duyuşsal alanda meydana gelecek etkileşimler insanın bilişsel düzeyini tetikleyerek devinimsel becerileri eyleme geçirir. Duyuşsal alan ilgi, tutum, algı v.s. gibi özellikleri kapsamaktadır. Bu maksatla insanın doğaya karşı ilgisi, insan ve doğa arasında kurulacak bağın önem düzeyiyle ilişkilendirilerek doğa eğitimiyle ilgili mesajların planlı bir şekilde aktarımıyla artırılabilir (Atasoy, 2006; Güler, 2009; Palmberg ve Kuru, 2001; Phenice ve Griffore, 2003; Ozaner, 2004;). Doğaya yönelik artırılan ilgi sayesinde diğer olumlu davranışlar da tetiklenir; böylelikle daha hedef kitle aktive edilerek daha korumacı, güzelleştirici ve sürdürülebilir çevre hareketleri meydana getirilebilir.

Çevre sorunlarını sadece teknik bir olgu olarak görerek insan-doğa ilişkilerini göz ardı eden, örgün ve yaygın eğitime yeterli şekilde odaklanmayan ve katılımcılığı önemsemeyen "sığ çevreci" yaklaşımlar yetersiz kalmaktadır (Tlert, 1998). Özellikle geliş̧mekte olan ülkelerde örgün eğitim programlarının doğa-çevre konusunda yetersiz olduğu bilinmekle beraber çevre/doğa eğitimleriyle toplumda dikkate değer oranda olumlu değişimler meydana geldiği gözlenmiştir (Güler 2009; Malone ve Tranter, 2003). Keza, Doğa ve çevre sorunlarını çözmek için teknik alt yapıların iyileştirilmesi de yeterli değildir. İşe yarar çözümler üretmek için insana doğayı koruma bilincinin aşılanması gerekmektedir. Bu ise ancak doğa içerisinde planlı eğitimlerle gerçekleştirilebilir.

Türkiye'de çevre-doğa eğitiminin yetersizliğine vurgu yapan araştırmalar göze çarparken (Soran, Morgil, Yücel ve Işık, 2000; Yılmaz, Morgil, Aktuğ ve Göbekli; 2002), Dünya'da ise doğayı koruma yolunda istendik davranışlar oluşturulmasına yönelik projeler çoğalıp yaygınlaşmaktadır (Alkan ve Korkmaz, 2009; Noughton-Treves, Holand ve Brondon, 2005). Doğa eğitimi yönündeki etkinliklerin gelişmiş ülkelerde son yılların popüler çalışmaları olarak dikkat çektiği görülmektedir. Ülkemizde de örgün eğitim programlarının doğa-çevre eğitimi konusundaki yetersizliklerinin giderilmesi ve doğa dostu bireylerin topluma kazandırılmasına hizmet eden "Doğa Eğitim Projeleri" son yıllarda TÜBiTAK (Türkiye Bilimsel ve Teknolojik Araştırma Kurumu) tarafından önemsenip desteklenerek yaygınlaştırılmaya çalışılan projeler haline gelmiştir (Oğurlu ve Alkan, 2012). Özellikle milli parklar ve benzeri doğal korunan alanların bulunduğu yöreler, doğa eğitim projeleri için tercih edilen yerler olmaktadır (Oğurlu vd., 2010). Doğanın korunmasına ve doğa koruma bilincinin oluşturulmasına yönelik eğitimlerin etki düzeyini ortaya çıkaracak deneysel verilere intiyaç duyulmaktadır. Doğa eğitimlerinde bu katılımcı gözlemleri ve katılımcıyla yapılan görüşmelerle sağlanmaya çalışılmaktadır.

Doğa eğitim projeleri, doğa ve doğal varlıkların tanıtımı ve korunmasına önemli katkı sağlamakta ve etkin potansiyeli olan aktif bir kitle oluşturabilmektedir. Ayrıca bu projeler katılımcılar üzerinde hem kavramsal hem de pratik bilgilenme ve bilinç düzeylerini geliştirme bakımından önemli derecede etkili olmaktadır (Oğurlu ve Alkan, 2012). Öğretmenler, öğretmeöğrenme sürecinin ana unsurudur. $O$ halde, başta, eğitimin her kademesinde görev yapan öğretmenlerin çevre konusunda duyarlı ve bilgili olmaları gerekmektedir. Öğretmenlerin çevre/doğa eğitimi için hem istikrarlı bir danışmanlığa, hem de kaynak, araç-gereç ve materyale intiyaçları bulunmaktadır (Arslan, 1997). Buradan yola çıkılarak, 2007-2010 yılları arasında Isparta'nın milli park ve tabiat parkı gibi korunan doğal alanlarında gerçekleştirilip aynı zamanda bu makalenin konusunu oluşturan bir dizi doğa eğitim projesi (IDE projeleri) için de hedef kitle olarak öğretmenler ve aday öğretmenler seçilmiştir. 
TÜBITAK eliyle 1999 yılından itibaren gerçekleştirilmeye çalışılan doğa eğitimi projeleri (Ozaner ve Yalçın, 2001) daha sonraki yıllarda farklı yürütücüler tarafından TÜBiTAK desteğiyle ülke genelinde yürütülmeye başlanmıştır. 2007 yılında gelindiğinde doğa eğitim proje sayısı 13' e çıkmış olup desteklenmesine karar verilen projeler arasında IDE projesi de yer almaktadır. Sonraki yıllarda aynı logoyla devam eden ve Isparta Korunan Doğal Alanlarında Doğa Eğitimi (IDE) adıyla tanınan bu projelerden ilk üçü TÜBiTAK'ın, IDE-1(proje no: 107B031), IDE-2 (108B015) ve IDE-3 (110B089) olarak destek sağladığı projelerdir. Sonuncusu 2014 yılında IDE-6 adıyla yürütülün bu proje serisinden; ekip, içerik, yöntem, etkinlik alanı ve etkinlik türü olarak en fazla benzeşmesi dolayısıyla birlikte değerlendirilebilecek olanlar (IDE-1,2 ve 3 projeleri) bir araştırma kapsamında ele alınarak değerlendirilmiştir.

$\mathrm{Bu}$ araştırmanın amacı, IDE kapsamında verilen eğitimin öğretmen ve aday öğretmenlerin doğaya ve doğa eğitimine bakışlarını nasıl etkilediğini belirlemektir. Bu amaçla, aşağıdaki sorulara cevap verilmeye çalışılmıştır:

1. Katılımcıların doğa projelerine katııım tercihlerini etkileyen faktörler nelerdir?

2. Katılımcıların doğa projelerinden sürdürülebilir çevre ve doğaya yönelik kazanımları nelerdir?

3. Doğa projeleri eğitimi katılımcıların kazanımlarını yaymaya yönelik görüşlerini nasıl etkilemektedir?

4. IDE doğa projelerinin yeterliliğine ilişkin katılımcıların görüşleri nelerdir?

5. IDE eğitim alanına yönelik katılımcıların görüşleri nelerdir?

6. Doğa projelerinde çadır kamplarına ilişkin katılımcıların görüşleri nelerdir?

7. IDE doğa projelerinin geliştirilmesine yönelik katılıcıların önerileri nelerdir?

8. Doğa projelerinin sosyal sorumluluğu üzerine katılımcıların görüşleri nelerdir?

\section{YÖNTEM}

\section{1. Çalışmanın Deseni}

Doğa eğitim projelerinin sonuçları değerlendirilirken hem nicel hem de nitel araştırma tekniklerinden yararlanıldığı görülmektedir. Mesela, anket gibi yapılandırılmış araçların verileri istatistik analize tabi tutulmakta, buna mukabil olayların daha derinlemesine incelemesinde görüşme/röportaj gibi yarı yapılandırılmış metinleri ele alan nitel analizlerden de faydalanılabileceği belirtilmektedir (Yıldııı ve Şimşek, 2008). Bu araştırmanın materyali; doğa eğitimine katılan katılımcılarla yapılan anket-röportaj çalışması verileri ve erişime açık proje dokümanlarından (URL-1) oluşmaktadır. Yöntem ise anket ve röportaj teknikleriyle elde edilen verilerin nicel ve nitel değerlendirmesine dayanmaktadır.

Araştırmada nitel analiz olarak; farkında olunan, bununla beraber derinlemesine ve ayrıntılı araştırılmasına ihtiyaç duyulan konulara odaklanılmasında başvurulan olgu-bilim deseni kullanılmıştır. Burada amaç; Katılımcıların ne düşündükleri ve ne hissettiklerini görmek için sözel ve yazılı metinlerde saklı olan anlamların ortaya çıkarmaktır (Kuş, 2009). Çalışmanın nitel verilerini katılımcıların (çalışma grubu) doğa eğitim programlarının uygulanması ve kendilerini eğitim sonuçlarından ne yönde ve ne ölçüde etkilendiğine ilişkin görüşleri/ifadeleri oluşturmaktadır. Katılımcı görüşleri betimleyici yaklaşım esas alınarak nitel yolla irdelenmiştir.

Görüşme tekniğinde veriler, katılımcıların anlam dünyalarını, yaşadıklarını ve onları yorumlama biçimlerini ve ayrıca duygu ve düşüncelerini aktarmaktadır. Buradaki anlamlar, 
kültürel ve sosyal olarak inşa edildiği için nitel görüşme sırasında elde edilen veriler derin, zengin ve detay içermektedir (Kuş, 2009; Willis, 2007). Ancak nitel araştırmada toplanan verilerin ayrıntılı olarak rapor edilmesi ve araştırmacının sonuçlara nasıl ulaştığını açıklaması önemlidir (Yıldırım ve Şimşek, 2008). Bunun yanı sıra betimsel analiz tekniğinin kullanıldığı bir araştırmada, araştırmanın sonuçlarını görüşülen bireylerden doğrudan alıntılara yer vererek açıklamak, geçerliği sağlamaya yönelik önemli bir strateji olarak kabul edilmektedir (Yıldırım ve Şimşek, 2008). Bu maksatla görüşme ile ilgili veriler, her nicel verinin ardından görüşme tema/kod birlikteliği içerisinde içerik analizi ile çözümlenerek verilmiştir. Katılımcıyla yapılan görüşmelerin kayıtları görüşme soruları doğrultusunda ve içerik analizi aşamasında ortaya çıkan temalar çerçevesinde tartışılarak yorumlanmıştır.

Öğrenme alanlarına yönelik çalışmalarda ise nicel araştırma desenleri ile de veri toplandığı görülmektedir (Berberoğlu, Güder, Sezer, ve Yalçın-Özdilek, 2013; Yıldırım ve Şimşek, 2006). Dolayısıyla bir doğa eğitim programı sonunda katılımcılarda duyuşsal alana dair gelişmenin olup olmadığını incelerken "her metnin bir fikir, bilgi parçası ya da olayı ifade ettiği" görüşünden (Tesch, 1990) hareketle gerekirse doğa eğitim etkinliklerinden her birini bir olay/vak'a gibi kabul edip incelemek ve incelenen olaydan nitel değerlendirmeye imkân verecek veriler elde etmek veya verilerin temalar halinde gruplandırılması halinde frekans benzeri sayısal değerler elde etmek mümkündür. Bu ise hem nitel araştırma yöntemlerinden olgu-bilim deseninin kullanılmasına hem de anketleme tekniği gibi nicel yöntemlerin kullanılmasına imkân vermektedir. Doğa eğitim projelerinde nicel değerlendirmeye katılımcıdaki farkındalığı ve çeşitli yönlerdeki gelişimi ölçmeyi amaçlayan anketleme verilerini değerlendirirken sıkça başvurulmaktadır.

Katılımcıda eğitim etkinliğinden etkilenme ve istendik davranışa doğru bir gelişimin gerçekleşip gerçekleşmediğini anlamak için nicel araştırma yöntemleri yanında nitel araştırma tekniklerinden de yararlanılabileceği bilgisine dayanarak (Baş ve Akturan, 2008; Berberoğlu vd., 2013; Yıldırım ve Şimşek, 2006; Zanovello, 1999) ve betimsel analiz yaklaşımıyla olay/vak'a inceleme yoluna gidilmiştir. Röportajlarda veri toplamak için hazırlanmış olan sorularda kısmen yönlendirmede bulunmaktan kaçınılamayacağı bilindiğinden, katılımcıların düşüncelerini olduğu gibi yansıtabilmeleri için hem yazarken serbest bırakılmışlar, fakat yazdıkları her şey veri kabul edilmiştir.

Elde edilen nitel veriler, tabiatı gereği bir ölçüde yüzeysel niteliktedir. Bu sebeple nicel verilerle test ve teyit edilmesi gerekmiştir. Bu çalışmada IDE projelerini konu alan bazı yayınlarımızda da kısmen yer alan birtakım nicel verilerden de yararlanarak, bunlar IDE ağ sayfasında (URL-1) yayınlamış nitel verilerle birlikte analiz edilip yorumlanmıştır.

Araştırmanın nitel verileri katılımcılar üzerinde uygulanan röportaj (yarı yapılandırılmış görüşme) tekniği kullanılarak ve katılımcıların serbest ifadelerini içeren yazılı metinler elden geçirilerek toplanmıştır. Röportajlarda görüşmeler kaydedilmiş, yapılan görüşmelerin ses kayıtlarının deşifre işlemleri ve doküman incelemesi tamamlandıktan sonra alıntılar yapılmış ve yapılan alıntılar sınıflandırıımıştır.

Röportajda kullanılan açık uçlu soruları belirlemek için öğretmenlerin çevre eğitimi üzerine yapılmış araştırmalar (Genç, 2015; Erol ve Gezer, 2006; Erten, 2003; Payne, 2006; Pitman, 2004) gözden geçirilmiştir. Diğer yandan, IDE eğitim programı çerçevesinde yapılan her bir etkinlik bir olay gibi düşünülmüş ve röportaj verme, günlük tutma ve serbest ifade gibi eşitli araçlarla katılımcı yaşadığı bu olay hakkındaki duygu ve düşüncelerini ifade etmeye teşvik edilmiştir. Buna örnek olarak projenin web sayfasındaki 'Seher Yürüyüşleri" veya "Katılımoı Gözüyle IDE" metinleri (URL-2) incelenebilir. 
Sosyal yönü olan bir araştırmada verilerin güvenilirliği açısından farklı yöntemler ile de veri toplanmasının daha uygun olduğu belirtilmektedir (Vidich, 1955). Bu sebeple ayrıca, gözlem yöntemiyle de veri toplanmaya çalışıımış (Baş ve Akturan, 2008) ve her etkinlik döneminde eğitmenler arasından seçilen bir proje elemanı etkinlik süresince bir yandan yapılan etkinliğin ayrıntılarını not alırken bir taraftan da katılımcıların tepkilerini gözlemleyerek not almıştır. IDE Günlüğü adı verilen bu dokümanlardaki kayıtlar (URL-3). Katılımcı davranışlarını açıklamada kullanışı veriler sağlamıştır. Bu notlardan da belli ölçüde kalmak kaydıyla, katılımcılarda görülen davranış türlerinden; ilgi, keşfetme, aktif katııım vb. gibi davranışlara ait nitel değerlendirmeler yapılabilmiştir.

Anketler her dönem, ilki eğitim programı başlangıcında ikincisi de program sonunda olmak üzere iki farklı form (URL-1) yardımıyla uygulanmıştır. Araştırmadaki nicel değerlendirmeler bu formlardan alınan verilere dayanmaktadır.

Nitel değerlendirmelerin temelini ise katılımcıların serbest ifadelerinden oluşan metinler veya yarı yapılandırılmış röportajların verileri teşkil etmektedir. Katılımcı ifadelerini içeren ve aynı zamanda nitel değerlendirmelerin dayandığı kaynak metinler IDE web sitesinde 2007 yılından bu yana erişime açık hâldedir.

Tablo 1

Çalışmanın Deseni

\begin{tabular}{lllll}
\hline İşlem & Uygulama & Nicel Yöntem & Nitel Yöntem & Analiz türü \\
& Biçimi & & & \\
\hline Görüşme & Eğitim sonu & - & Olgu bilim & İçerik \\
Günlük tutma & Eğitim boyu & - & - & İçerik \\
Anket-1 & Eğitim baş̧ı̧̧ & Taraması & - & Betimsel \\
Anket-2 & Eğitim sonu & Tarama & - & Betimsel \\
Anket-3 & Eğitimden üç ay & Tarama & & Betimsel \\
(İzleme) & sonra & & Olgu-bilim & İçerik \\
Gözlem & Eğitim boyu & - & &
\end{tabular}

\subsection{Verilerin Toplanması}

\subsubsection{Proje Eğitim Süreci}

Projeler 2007-2010 yılları arasında üç yıla yayılan ve genellikle bahar-yaz ve güz aylarına isabet eden birer haftalık 11 ayrı eğitim döneminde tamamlanmış ve bu eğitim programları sonunda katılımcılara "Doğa Eğitim Sertifikası" verilmiş̧ir. Projelerin eğitim dönemleri;

IDE-1: Temmuz 2007, Eylül 2007 ve Şubat 2008

IDE-2: Mayıs 2008, Haziran 2008, Ağustos 2008 ve Ekim 2008

IDE-3:Temmuz 2010, Ağustos 2010, Eylül 2010 ve Ekim 2010 şeklindedir.

Proje eğitim alanı olarak 2 adet milli park, 2 adet tabiatı koruma alanı, 3 adet tabiat parkı, çok sayıda tabiat anıtı ve diğer statüde korunan doğal alanlara sahip olan (Alkan ve Korkmaz 2009) Isparta ili seçilmiştir.

Aktif öğrenmeyi çevre eğitiminin duygusal, etik ve davranışsal hedeflerini başarmanın anahtarı olduğu ifade edilmektedir (Benedict, 1991; Haktanır, 2007). Buradan hareketle, eğitim etkinlikleri kısmen teorik çoğunlukla da doğada gözleme dayalı olarak (görseluygulamalı) gerçekleştirilmiştir. Dersler, olabildiği ölçüde doğa ile doğrudan temas halinde işlenmiş ve Eğitimde "Merak et!, Öğren! Ve Uygula! Modeli” kullanılmıştır 
Proje (IDE) kapsamında verilen eğitim ekoloji temellidir. Bununla beraber eğitim programında ekolojinin yanı sıra biyoloji, coğrafya, sosyoloji, doğa felsefesi, planlama ve yönetim gibi farklı bilim dallarına ait ders ve uygulamalara yer verilmiştir. Konular; arazide yerinde gözlemlerle, katılımcı ve sorgulayıc bir yaklaşımla, çözüm üreterek işlenmektedir. Böylece, doğada gözlem yapma fırsatı verilerek, bilimsel araştırmaları sevdirmek, ilgili konularda katılımcıların kendilerini geliştirmelerine katkıda bulunmak ve çevre bilincinin artmasını sağlamak amaçlanmaktadır. Nitekim Doğa eğitim projelerinden umulanın; bunların yaygınlaşıp katılımcıların bu eğitimlerle kazanacakları bilgi ve tecrübeyi; yakın çevreleri ve eğitim kurumlarındaki öğrencileriyle paylaşmaları, geldikleri illere dönünce benzer çevre/doğa eğitimleri düzenlemeleri (Ozaner, 2004) olduğu ifade edilmektedir.

IDE projelerinin amacı Doğa gönüllüleri ile uzmanlarını doğada bir araya getirerek ve bilgi paylaşma tarzında aktif bir eğitime tabi tutulmasıdır. Bu ihtiyacının karşılanmasına yönelik olarak projeler için şu hedefler belirlenmiştir:

1. Doğa ve ekoloji alanındaki bilgileri doğada serbest aktivitelerle ve katılımcı bir eğitim programı çerçevesinde katılımcılara aktararak onlara doğa dili ve eğitimini öğretmek,

2. Katılımcılara doğayı "görme" ve "gösterebilme" kabiliyeti, yani doğayı tanıyıp anlayabilme ve gördüklerini öğrencilerine/çevrelerine aktarabilme nosyonu ve çevrelerini etkileme gücü/yetisi kazandırmak,

3. Çevre ve Doğa eğitiminde disiplinler arası ve bütüncül bir eğitim-öğretim formatı ve doğa eğitimi vizyonu gelişmesine katkıda bulunmak.

Kovada Gölü Milli Parkı, Kızıldağ Milli Parkı, Beyşehir Gölü Milli Parkı, Gölcük Tabiat Parkı, Kasnak Meşesi Tabiatı Koruma Alanı, Yazılı Kanyon Tabiat Parkı, Kovada Çayı Arboretumu, Eğirdir Gölü, vb. birçok korunan alan IDE Projelerinin eğitim etkinlikleri için kullanılmıştır. Birer haftalık eğitim dönemlerde 2-3 gün çadırlarda konaklanmış (kamping), katılımcıların yeme içme dâhil her türlü ihtiyaçlarını doğada karşılamaları sağlanmıştır. Eğitim programı içinde hayatta kalma, ilk yardım teknikleri, kamp kurma ve malzeme kullanımı, gözlem araç-gereçlerinden yararlanma, kayda alma teknikleri, fotoğraf/video çekimleri, doğal koleksiyon teknikleri, doğa oyunları, doğa yürüyüşleri, yaban hayatı ve vejetasyon gözlemleri, gökyüzü gözlemleri, jeolojik ve ekolojik gözlemler, kırsal toplum ve yerel halk gözlemleri, peyzaj ve görsel değer analizleri gibi birçok etkinliğe yer verilmiştir (IDE-1, 2007; IDE-2, 2008; IDE-3, 2010; Oğurlu vd., 2010). Proje hakkındaki diğer ayrıntılara 2007 yılından beri kesintisiz yayında olan proje sitesinden (URL-1) erişilebilmektedir.

\subsection{2. Çalışmada Nicel Veri Toplama Süreci}

Çalışmada eğitim dönemi başlangıcında (ilk anket), dönem sonunda (ikinci anket) değerlendirme) ve eğitimin bitişini takiben 3 ay sonra (izleme anketi) olmak üzere toplam üç farklı anket uygulaması gerçekleştirilmiştir. Birinci anket katılımcı profillerini, öğretmen ve öğretmen adaylarının doğa eğitimi hakkındaki mevcut algı ve düşüncelerini, projeye katılım kararına etki eden faktörleri, beklentileri ve mevcut bilgi düzeyini belirlemek için; ìkinci anket ise katılımcıların proje ile bilgi düzeylerinde bir değişimin oluşup oluşmadığı, katılımcıların projeyi içerik, eğitmenler, uygulama alanları, vb. itibariyle yeterli görüp görmediği gibi hususların belirlenebilmesi amacıyla gerçekleştirilmiştir.

Anket formlarında çoktan seçmeli ve eşit aralıklı dereceli sorulara yer verilmiştir. Dereceli sorularda kullanılan ölçek $4^{\prime} l u ̈$ likert tipi ölçeklerdir. Ölçek güvenilirliğinin test edilmesi 
amacıyla Cronbach Alfa Katsayısı (alfa yöntemi) kullanılmıştır. Katsayı 0.896 olarak hesaplanmış ${ }^{1}$; kullanılan ölçeğin yüksek güvenilirlikte olduğu tespit edilmiştir.

\subsection{3. Çalışmada Nitel Veri Toplama Süreci}

Çalışmanın nitel verilerini katılımcıların (çalışma grubu) doğa eğitim programlarıın uygulanması ve kendilerini eğitim sonuçlarından ne yönde ve ne ölçüde etkilendiğine ilişkin görüşleri/ifadeleri oluşturmaktadır. Araştırmanın nitel verileri katılımcılar üzerinde uygulanan röportaj (yarı yapılandırılmış görüşme) tekniği kullanılarak ve katılımcıların serbest ifadelerini içeren yazılı metinler elden geçirilerek toplanmıştır. Röportajlarda görüşmeler kaydedilmiş, yapılan görüşmelerin ses kayıtlarının çözümleme işlemleri ve doküman incelemesi tamamlandıktan sonra alıntılar yapılmış ve yapılan alıntılar sınıflandırılmıştır. Diğer yandan, IDE eğitim programı çerçevesinde yapılan her bir etkinlik bir olay gibi düşünülmüş ve röportaj verme, günlük tutma ve serbest ifade gibi eşitli araçlarla katılımcı yaşadığı bu olay hakkındaki duygu ve düşüncelerini ifade etmeye teşvik edilmiştir. Ayrıca, gözlem yöntemiyle de veri toplanmaya çalışıımış (Baş ve Akturan, 2008) ve her etkinlik döneminde eğitmenler arasından seçilen bir proje elemanı etkinlik süresince bir yandan yapılan etkinliğin ayrıntılarını not alırken bir taraftan da katılımcıların tepkilerini gözlemleyerek not almıştır.

\section{3. Çalışma Grubu}

Araştırma çalışma grubunu 2007 Temmuz- 2010 Ekim tarihleri arasında gerçekleştirilmiş üç ayrı projenin (Isparta korunan Doğal Alanlarında Doğa Eğitimi I, II ve III) 11 ayrı dönemde yapılan eğitim etkinliklerine katılan 227 katılımcı oluşturmaktadır. Birinci ve ikinci anketler; IDE-1 projesinde 2007 yılının Temmuz ve Eylül ayları ile 2008 Şubat'ına rastlayan 3 etkinlik döneminde; IDE-2 projesinde 2008 Mayıs- Haziran- Ağustos ve Ekim dönemleri olmak üzere 4 dönemde ve nihayet IDE-3 projesinde 2010 Temmuz- Ağustos-Eylül ve Ekim olmak üzere 4 dönemde projeye iştirak edenlerin toplamı olan 227 katılımcıya uygulanmıştır.

IDE projelerine katılan öğretmen ve öğretmen adaylarının yaklaşık \% 53'ü bayan ve \% 47 'si erkektir. Katılımcıların yaklaşık \%24'i sınıf öğretmenliği, \%17'si coğrafya, \%28'i biyoloji, $\% 21^{\prime} i$ fen bilgisi ve $\% 10^{\prime} u$ da resim öğretmenliği, sosyal bilgiler öğretmenliği, vb. gibi diğer branşlardandır.

IDE projelerine; Sınıf öğretmenleri, fen bilgisi, biyoloji, coğrafya, sınıf öğretmenliği branşlarındaki öğretmen ve öğretmen adayları dışında ve bunlar dışında izci liderliği gibi pozisyonlara sahip az sayıda katılımcı kabul edilmiştir.

Birinci ve ikinci anket çalışmasına dair değerlendirmeler 203 anket üzerinden yapılmıştır ${ }^{2}$. İlk iki anketleme çalışmasında katılımcılar çalışma hakkında bilgilendirilip kendilerine anket formları dağıtılmış, doldurulan formlar bir gün sonra toplanmıştır. Üçüncü anket çalışması ise proje kazanımlarının izlenmesi ve geri bildirim sağlanması amacıyla her bir eğitim dönemi tamamlandıktan 3 ay sonra elektronik ortamda gerçekleştirilmiştir. 227 katılımcının tamamının dâhil edileceği bir anketleme planlamanın, yani bu 3 projeye

${ }^{1} 0.80<\alpha<1.00$ : Yüksek güvenilirlik

2 IDE-2 Ekim 2008 dönemi katılımcıları ile eğitim programı başlangıcında anket çalışması yapılmasına rağmen; program sonrası anket uygulaması gerçekleştirilememiştir. 
katılanların hepsiyle birden anket yapmanın zorluğu göz önüne alınarak, izleme anketi örneklemeye dayandırılmıştır Örnek büyüklüğü aşağıdaki formüle (Karasar 1994; URL-1, 2011) göre hesaplanıp 68 olarak belirlenmiştir.

$$
\text { SS }=\frac{Z^{2} x(p) x(1-p)}{C^{2}}
$$

\subsection{Verilerin Analizi}

\subsubsection{Nitel Verilerin Analizi}

Katılımcıların eğitim programındaki çeşitli gözlem etkinliklerini hangisinden ne kadar etkilendikleri veya hangisiyle ne ölçüde farkındalık kazandıklarını kendi ifadelerine dayanarak bulmak için Tablo 2'de yapıldığı gibi katılımcı ifadesinde adı zikredilen etkinlik işaretlenerek çetele tutulmuş ve böylece "etkinlik etkileme frekansları" hesap edilmiştir.

Tablonun ilk sütununda proje numarası (IDE 1, 2, 3 gibi) ve dönemi (1 dönem, 2 dönem gibi) ile katılımcı ad ve soyadından yararlanarak oluşturulan kodlar kullanılmıştır. Aynı kodlar makalenin Bulgular bölümünde katılımcıların serbest ifadelerinden örnek verirken de kullanılmıştır. Kodu oluşturan karakterlerden ilki metin türünü, yani röportaj (R) mı, yoksa proje web sitesinde 'Katılımcı Gözüyle IDE' başlığı altında verilen serbest ifadelerden biri (S) mi olduğunu, 2. karakter projenin kaçıncı IDE olduğunu, 3. karakter o yılki projenin hangi dönemi olduğunu, 4. ile 5. ve varsa 6 . karakterler ise katılımcının ad ve soyadının ilk harflerini ifade etmektedir. Örneğin IDE 2 Projesi 1 Etkinlik döneminde kendisiyle röportaj yapılan VÇ'nin ifadesi makalede; R21VÇ: "...bütün gördügümüz iğne yapraklı ağaçları çam olarak ifade ediyorduk." şeklinde verilmiştir.

R12SY: "Sabahın erken saatlerinde bir kuzgunun doğal alanındaki yaşayışına şahit olduk; bu unutulmaz bir bilgi edinme yolu.." şeklindeki gösterim ise bu aktarılanın IDE-1 projesi 2. etkinlik dönemine katılan SY adlı sınıf öğretmenine ait bir ifade olduğunu anlatmaktadır.

Tablo 2

Katılımcıların IDE Projelerindeki Farklı Eğitim Etkinliklerinden Etkilenme Durumunun Gösterilmesi

\begin{tabular}{|c|c|c|c|c|}
\hline $\begin{array}{l}\text { Katılımcı } \\
\text { kodu }\end{array}$ & $\begin{array}{l}\text { Yaban Hayatı ve } \\
\text { Kuş Gözlemleri }\end{array}$ & $\begin{array}{l}\text { Vejetasyon ve } \\
\text { Flora Gözlemleri }\end{array}$ & $\begin{array}{c}\text { Peyzaj/Manzara } \\
\text { Değerleri }\end{array}$ & Diğerleri \\
\hline P11AE & $x x$ & $x$ & $x$ & \\
\hline P11ŞA & $x x$ & & $x$ & $x$ \\
\hline S11MÖ & $x x x x$ & $x$ & $x$ & $x$ \\
\hline . & . & . & . & . \\
\hline . & . & . & . & . \\
\hline$\downarrow$ & $\downarrow$ & $\downarrow$ & $\downarrow$ & $\downarrow$ \\
\hline $\begin{array}{l}\text { Toplam } \\
\text { frekanslar }\end{array}$ & 106 & 55 & 46 & 29 \\
\hline$\%$ Oran & 46 & 23 & 19 & 12 \\
\hline
\end{tabular}

Aynı şekilde, Katılımcının etkinliklere ve tüm eğitim programı hakkındaki düşüncelerini belirleyebilmek için yazdıkları da gözden geçirilerek katılımcı görüş, duyuş ve fikirlerinden oluşan temalar belirlenmiş ve böylece verilerin kodlaması gerçekleştirilmiştir. Temaların tanımlanması için bu kodlamalar (Shanely, 2006) kullanılmıştır. Gerektiğinde örnek olay incelemesine gitmek için projenin web sitesinde (URL-1) açık erişim dokümanlarından veri alınmıştır (Yıldırım ve Şimşek, 2006). 


\subsubsection{Nicel Verilerin Analizi}

Değerlendirmelerde SPSS paket programı ve Excel yazılımı kullanılmış; bulgular kullanılan soru ve ölçeklerin özelliklerine göre bazen frekanslar, bazen öncelikler, bazen de değişkenler arası ilişkiler şeklinde sunulmuştur. Dönem başı ve sonu değişkenler arası farklıkların belirlenmesi ve değişkenler arası ilişkilerin tespiti için çapraz tablo matrisleri ve Ki Kare analizi kullanılmıştır. Katılımcılara IDE eğitim projelerine katıım kararında etkili olan potansiyel faktörler, önermeler halinde sunulmuş (Tablo 3) ve katılımcıya bu önermelerin önem ve öncelik düzeylerini ifade etmeleri istenmiştir. Keza, katılımcıların eğitim öncesi çeşitli konular hakkında sahip oldukları bilgi düzeylerini ve program sonunda ortaya çıkan gelişimi ölçmek için katılımcıları program başlangıında ve proje bitiminde belirlenen önerme şeklinde 11 tema sunulmuş ve katılımcıdan bunları derecelendirmeleri istenmiştir.

\section{BULGULAR}

\subsection{IDE Doğa Projelerine Katılım Tercihlerine iliş̧kin Bulgular}

Katılımcıların IDE eğitim projelerine katılmalarında Tablo $3^{\prime}$ deki önermelerden hangilerinin ne derecede etkili olduğu sorulmuş ve bunların önem ve öncelik düzeylerini ifade etmeleri istenmiştir. Ortaya çıkan sonuç Tablo 3'de gösterilmektedir.

Illk anket verilerine göre Tablo 3'de görüldüğü gibi katılım kararına etkili olan faktörler içinde "boş zamanları değerlendirme fırsatı $(\overline{\mathbf{x}}=\mathbf{2 . 5 0})$ ", "ücretsiz gezme imkanı sağlaması $(\overline{\mathbf{x}}=\mathbf{2 . 4 8})$ " gibi faktörler önem ve öncelik bakımından en gerilerde kalırken; "doğayı tanıma, bitkisel ve hayvansal varlıkları ve yaşama ortamlarını daha iyi tanıma $(\bar{x}=3.52-3.82)$ "; "öğrencilerime doğayı daha ayrıntılı ve bilimsel olarak anlatma fırsatı sağlaması $(\overline{\mathbf{x}}=3.81)$ " gibi faktörler öne çıkmıştır. Anket verilerinin nicel değerlendirmesinde bu durum açıkça görülmektedir. Yani, katılımcılar büyük oranda; doğayı doğada tanımak, yaşayarak yerinde öğrenmek ve öğrencileriyle paylaşabilecekleri kalıcı bilgiler edinme düşüncesiyle projeye katıldıklarını ifade etmektedirler. Nitekim Benzer tespitler diğer bazı çalışmalarda da yapılmıştır. Mesela Güler (2009) öğretmenlerin, en çok, doğayı daha iyi tanıma ihtiyacı ve edinilen bilgileri paylaşmak için eğitim projelerine katıldığını bildirmektedir.

Tablo 3

IDE Projelerine Katılanların Katılma Kararında Etkili Olan Faktörler ve Öncelikleri*

\begin{tabular}{lc}
\hline \multicolumn{1}{c}{ Potansiyel Faktörler } & $\overline{\boldsymbol{x}}^{* *}$ \\
\hline Yeni yerler görme arzusu & 3,63 \\
Doğa/Kırsalda yaşayan köylüler ve doğa-insan etkileşimiyle ilgili ayrıntılı bilgi edinme ihtiyacı & 3,52 \\
Yaban hayvanları ve fauna hakkında daha ayrıntılı bilgi edinme ihtiyacı & 3,71 \\
Flora, bitki türleri ve ağaçlar hakkında daha fazla bilgi edinme ihtiyacı & 3,69 \\
Peyzaj ve görsel değerler hakkında daha ayrıntılı bilgi edinme ihtiyacı & 3,33 \\
Bitkisel ve hayvansal varlıkları ve yaşama ortamlarını daha iyi tanıma ihtiyacı & 3,82 \\
Bir yıla ait yorgunluğu atmak için iyi bir fırsat olur düşüncesi & 2,40 \\
Yeni insanlarla özellikle de doğaseverler ve bilim adamlarıyla tanışma fırsatı elde etme & 3,67 \\
Öğrencilerime doğayı daha ayrıntılı ve bilimsel olarak anlatma fırsatı sağlaması & 3,81 \\
Boş zamanımı değerlendirme fırsatı sunması & 2,50 \\
Eğitim programının ücretsiz olması & 2,48
\end{tabular}

Tablo 3'deki “*” işareti verilerin birinci anketten elde edildiğini göstermektedir. Tablo 3'deki ortalama değerlerin 4'lü derecelendirmeye göre dağılım aralıkları"1: Hiç önemi yok, 2: Biraz önemli, 3: Orta derecede önemli, 4: Çok önemli" şeklinde betimlenmiştir. 
Tablo 3' nicel verilerden çıkan sonucun da katılımcıların aşağıdaki ifadelerine dayanan nitel değerlendirmemizle paralel olduğu görülmektedir. Nitel değerlendirmede kullanılan katıımcı ifadeleri analiz edildiğinde katılımcıların doğayı doğada tanıma, yaşayarak öğrenme ve öğrencileriyle paylaşma gibi geliş amaçlarına mukabil proje sonunda hangi noktaya geldikleri detaylandırılabilmektedir. Mesela, R11HÇ kodlu katıımcının ifadesi: "doğayı doğada öğrenme imkânı olunca daha kalıcı bilgiye sahip olunuyor." şeklinde, bir başka katılımcının (R23MKY) ifadesi ise "teoriden ve anlatımdan daha çok yaşayarak ve özellikle doğa eğitimi vereceksek eğer, mutlaka yerinde verilmesi gerekiyor." şekildedir: Diğer katılımcıların ifadeleri arasında aşağıdakilere benzer birçok örneğe rastlamak mümkündür. Mesela;

R23GÖ: "Doğa....yeni türleriyle tanışmak... kendimi geliştirmek... kendimi geliştirirsem öğrencilerimi de geliştiririm diye düşündüm." demektedir.

R23OBS: “...önce kendimiz doğayı tanıyacağız ki çocuklarımıza daha iyi bilgi verip daha iyi yetiştirelim... yaparak yaşayarak öğrenmek çok daha kalıcı bir etki sağlıyor. Biz bunu sınıf ortamında çıkarıp doğa ile buluşturursak daha başarılı olacaklar. ...(öğrencilerimin) daha çok doğada yer almalarını sağlayıp onları her fırsatta doğaya çıkaracağım."

R12MO: "Gelmeden önce, doğayı sevmek ve koruma konusunda kendimi yeterli hissediyordum; ama buraya gelince bu konudaki eksikliğimi fark ettim. Doğanın kendisini doğrudan gözlemlemek kesinlikle bambaşka bir öğrenme yöntemi ve akılda kalıcı. Edindiğim bu bilgi ve tecrübeyi öğrencilerime aktarmaya çalışacağım."

R12MÖ: "Örneğin bir kanyonun ne olduğunu oluşumunu okuyarak değil de içinden geçerek, yaşayarak, bakarak ve görerek öğrendik. Bu eğitimin benim kişisel gelişimimde çok faydalı olduğunu düşünüyorum dolayısılla bu gelişimin, doğrudan öğrencilerimin eğitimine yansıyacağını söyleyebilirim."

R31iA: "Eğitim sırasında gözlem yapmayı öğrendim. ileride tabiata geziye gittiğimde elimde bir dürbün olacak ve doğada gözlem yapacağım, öğrencilerime de bunu aşılayacağım."

S11NE: "... yaparak, yaşayarak ... öğrendim. Jeoloji- meteoroloji- yaban hayatı ... peyzaj ... Öğrendiklerimizi ... öğrencilerime aktarmayı görev sayıyorum."

S11VÇ: "Eksiklerimi görerek öğrenme yoluyla pekiştirdim. Bundan sonra çevremdekilere daha iyi aktaracağım inancındayım."

$\mathrm{Bu}$ ifadelerde görüldüğü gibi katılımcılar burada, nicel değerlendirmeyle tespit edilebilen (Tablo 4) bilgi düzey artışının nasıl gerçekleştiğine dair ipuçları veren detaylara girmektedirler.

IDE eğitim projelerine katılım kararına etki eden en önemli etmenlerden birisi de yeni insanlarla özellikle de doğaseverler ve bilim adamlarıyla tanışma ve paylaşım fırsatı sağlaması olarak ortaya çıkmıştır (Bkz Tablo 4). Eğitimin başında yapılan anketin sonuçları katılımcıların bu yöndeki beklentisinin yüksek olduğuna ve eğitime katılmalarında bu beklentinin oldukça etkili bir faktör olduğuna (Tablo 4) işaret etmektedir. Eğitim sonunda kaydedilen serbest ifadeler ise projenin katılımcıların bu beklentisine karşıladığını göstermektedir. Katılımcı ifadelerinden bazı örnekler aşağıdaki gibidir:

S12ŞAY: "Değerli bilim adamlarımızı ve doğa aşığı diğer katıımcı arkadaşları tanıma firsatı buldum." 
S13BY: "Yeni hocalarımızla, yeni arkadaşlarla-meslektaşlarla tanıştık ve çok şey paylaştık."

S11AC: “...ben bu etkinlikten büyük zenginliklerle ayrılıyorum. ...zenginlik; başta eğitmenlerimizden aldığımız bilgiler olmak üzere ... tanıdığım yeni kişilikler ve siz değerli hocamızın deneyimleri..."

S11EÖ: "Değerli, kaliteli, verimli bilim adamları ile tanıştım. Var olan bilgimi her yönden (taş, flora, fauna, peyzaj...) geliştirme fırsatı buldum."

\subsection{IDE Doğa Projelerinin Katılımcıların Sürdürülebilir Çevre ve Doğa Kazanımlarına}

\section{Yönelik Bulgular}

Tablo 4' de çeşitli konularda katılımcıların başlangıç ve proje bitimindeki bilgi düzeylerini 1: Hiç bilgim yok, 2: Biraz bilgim var, 3: Orta derecede bilgim var, 4: Çok iyi biliyorum ölçeğine göre değerlendirmeleri istenmiştir. Karşılaştırmaların anlaşılır olabilmesi için dereceli puanlar ortalama değerlere dönüştürülmüştür. Veriler non-parametrik olduğundan karşılaştırmalar frekans dağılımı üzerinden ki-kare testiyle yapılmıştır.

Tablo 4

Proje Eğitimi Sonunda Katılımcıların Tema Bazında Proje Kazanımlarına ilişkin Betimsel Dağılımları*

\begin{tabular}{|c|c|c|c|c|c|}
\hline & $\bar{x}$ & $\bar{x}$ & $\overline{\Delta x}$ & \multirow{2}{*}{$\begin{array}{c}\text { Ki Kare } \\
\left(x^{2}\right)\end{array}$} & \multirow[b]{2}{*}{$p$} \\
\hline Tema no ve Tema adı & $\begin{array}{l}\text { Proje Sonu } \\
\text { (IDE3) }\end{array}$ & $\begin{array}{l}\text { Proje Başı } \\
\text { (IDE1) }\end{array}$ & Değişim & & \\
\hline Orman kavramı ve Ülkemizin ormanları & 3,13 & 2,59 & 0,54 & 40,904 & 0,000 \\
\hline Doğal Korunan Alan Kavramı ve & 3,08 & 2,38 & 0,70 & 19,520 & 0,021 \\
\hline \multicolumn{6}{|l|}{ Ülkemizdeki Korunan Alanlar } \\
\hline 3. Tabiat parkı ve Ülkemizdeki tabiat parkları & 3,01 & 2,23 & 0,78 & 29,184 & 0,001 \\
\hline $\begin{array}{l}\text { 4. Milli park kavramı ve Ülkemizdeki milli } \\
\text { parklar }\end{array}$ & 3,11 & 2,37 & 0,74 & 23,262 & 0,006 \\
\hline Fauna ve Yaban hayvanları & 2,94 & 2,16 & 0,78 & 23,070 & 0,006 \\
\hline Çevre Jeolojisi ve Jeolojik yapı & 2,80 & 2,10 & 0,70 & 31,425 & 0,000 \\
\hline Bitkiler, Bitki türleri ve Botanik & 2,99 & 2,42 & 0,57 & 31,860 & 0,000 \\
\hline Kırsal Alanda İnsan ve çevre etkileşimi & 3,25 & 2,69 & 0,56 & 24,654 & 0,003 \\
\hline Ekolojik gözlem ve yorum & 3,03 & 2,40 & 0,63 & 29,874 & 0,000 \\
\hline 10. İklim ve Ormanların İklim Üzerine etkisi & 3,20 & 2,68 & 0,52 & 63,619 & 0,000 \\
\hline 11. Peyzaj ve görsel değerler & 2,74 & 2,00 & 0,74 & 14,591 & 0,103 \\
\hline
\end{tabular}

Tablo 4'deki “*” işareti verilerin birinci anketten elde edildiğini göstermektedir. Tablo 3'deki ortalama değerlerin 4'lü derecelendirmeye göre dağılım aralıkları"1: Hiç önemi yok, 2: Biraz önemli, 3: Orta derecede önemli, 4: Çok önemli” şeklinde betimlenmiştir.** $p<0,05$

Eğitim dönemleri sonunda yapılan ikinci anket verileri ilk anketler ile karşılaştırıldığında eğitimin katılımcının bilgi düzeyinin yükselmesine yaptığı katkı eğitimin her alanda/ temada başarılı olduğuna işaret etmektedir (Tablo 4). Katılımcılar, doğayla ilgili olarak verilen temalar hakkında eğitim öncesinde de belli ölçüde bilgiye sahiptir. Bu bilgilerini arttırmak için eğitime katılmaktadırlar. Benzer bulgular Güler (2009) tarafından da ortaya koyulmuştur. Araştırmada 11 tema halinde sunulan konuların tamamında artış gözlenmektedir. En önemli artışlar 3, 4, 5 ve 11 seçeneklerinde olmuştur. Tablo 4' deki nicel verileri projedeki nitel içerikli gözlem ve görüşmeler de desteklemektedir. Proje eğitim döneminin katılma amaçlarına ne ölçüde ve ne şekilde cevap verdiğini ve bunu sağlayan faktörlerin ne olduğunu ise nitel değerlendirmeyle 
anlaşılmaktadır. Katılımcılarla yapılan görüşmelerin örnekleri ve dağılımları aşağıda sunulmuştur:

Katılımcılarla yapılan görüşmelere göre onların en fazla etkilendikleri, ilginç buldukları ve yararlandıkları etkinlik türlerinin yaban hayatı ve kuş gözlemleri olduğu (\%46) anlaşılmıştır. Flora gözlemleri (\%23) ve peyzaj konulu etkinliklerin (\%19) de katılımcılar tarafından beğeniyle izlenen ve severek katıldıkları diğer etkinlikler olmuştur. Jeolojik gözlemleri, böcek gözlemleri veya gökyüzü gözlemlerini diğer bütün etkinliklerin toplamdaki oranı \%12 kadardır. En ağırlıklı grup olan yaban hayatı ve kuş gözlemlerini konu alan etkinliklerden katılımcıların etkilenme/yararlanma durumunu ifade eden ait bazı örnekler aşağıda verilmektedir: Örnekler bu verilenlerden ibaret olmayıp Bulgular bölümünde bunlara ait daha başka örneklere de yer verilmiştir.

R12FE: "Bir dağda bir hayvanın gelmesini-geçmesini sessizce ve saatlerce beklemek çok heyecan verici ve çok saygı duyulması gereken bir olay. ... Bir kuşu görebilmek için onun bulunduğu mekânı tarif edebilmem için yaşadıklarımı bile bambaşka bir heyecan."

R33HK : “... yaban hayvanlarının yaşadığı yerleri gördüm. Özellikle kuş gözlemleri beni çok etkiledi."

R12FE: “...kuş gözlemleri ve yaban keçisi gözlemlerinde çok heyecanlandım.”

R34MM: "Etkinlik olarak seher yürüyüşleri çok etkileyiciydi. Yaban hayvanlarını doğal ortamlarında görmek farklı bir duyguydu."

R31FD: "...bir hayvana bakınca bu kadar heyecanlanacağımı düşünemezdim. Yaban keçisini görünce çok heyecanlandım. Artık çevreme daha dikkatli bakmayı ögrendim"

Tablo 4; IDE projelerinin, katılanlara, Doğa hakkındaki bilgi düzeylerinin artması yönünde önemli katkılar ve farkındalık sağlamış olduğunu göstermektedir. Bu katkılar katılımcı -serbest- ifadeleri üzerinden nitel yolla da denetlenebilmektedir. İfade metinlerinde ayrıca bu katkıyı oluşturan unsurlar da analiz edilebilmektedir. Aşağıda bu ifadelerden örnekler verilmektedir (kaynak: URL-1röportajlar ve Katılımcı Gözüyle IDE sayfaları):

R22EG kodlu katılımcının ifadesi: "Mesela bastığımız ..taşın bile yalnız taş olmadığını, eskiden çam dediğimiz ağaçların bir kısmının çam olmadığııı, korktuğumuz böceklerin korkulmayacak şeyler olduğunu öğrendik...Derslerde öğrencilere .. kitaplardan .. bilgi aktarıyorduk. Ama şimdi .... bilerek anlatmak var. Yani duyup anlatmak bir de ögrencilere yaparak, geliştirerek, görerek anlatmak var. Biz burada bunu öğrendik.

IDE' ye kadar, benim gözümde orman, bir ağaçlar topluluğu idi (S12ART kodlu katılımal)

R23HE: "... böyle bir döngü olduğundan haberim yoktu. ...farkına vardık. .. Önceden, ormana bakış açımın çok dar olduğunu gördüm."

R23EK: "Şimdi ben çevre dediğimde ağaçlar, bitkiler ve hayvanlara daha dikkatli bir gözle bakıyorum. ...eskiden kuşları çok genelliyordum mesela. Ağaçlar hakkında da aynı şekilde.... çok ayrıntılı bakmıyordum. . Şimdi ... bu program sayesinde doğayı gerçekten daha iyi tanımış olduğuma inanıyorum."

S12EB: "Bu projeye kadar çevrede gördüğüm her kuş benim için sadece bir 'kuştu'. Proje sayesinde çevremdeki kuşları daha ilgiyle izler oldum." 
R21AK: "Doğada dengenin ne kadar özel ve ne kadar önemli olduğunu anladım. Bitki ve hayvanların denge açısından üstlendikleri rolü daha iyi algıladım."

R12MÖ: "Eğitime katıldığım ilk gün ile şu an arasında çok büyük farklııklar olduğunu söyleyebiliyorum. Artık ciddi anlamda doğaya bakış açımın değiştiğini görebiliyorum."

R12TÖ: "Doğa içerisinde "görmek" ile "bakmak" arasındaki farkı öğrendiğimi düşünüyorum."

R12FE: "Doğa uçsuz bucaksız bir keşif alanı. Bu alanda öğrenilecek keşfe açık o kadar çok şey var ki. Onu gördüm ben burada."

S21VÇ: "Birçok canlı türünü daha yakından tanıma fırsatı buldum. Şimdi çevreme her baktığımda yeni bir oluşum, yeni canlı türleri aramaya başladım. "

R34MA: "Hayvan türleri ile iz ve belirtileri konusunda farkındalık oluştu bende. Artık galiba yolda yürürken de iz arayacak gözlerim."

R21HC: "daha önce sadece kuş deyip geçiyordum... bilmiyordum. Şimdi ..."

R21TY: "önceden, kuş denince biz her gördügümüze serçe diyorduk. ...çocuklarımıza bunu vermeye çalışacağız. Bundan sonra okullarımızda..."

R31AE: "Daha önce de kuş gözlemine gidiyordum. Ama fark ettim ki o zamanlar tek bir şeylere odaklanıyormuşum. Şimdi hepsini aynı anda bir bütün olarak bakmayı ve düşünmeyi öğrendim. Ekolojisini, bitkisini, hayvanını, jeolojisini ...."

R34 SB (Coğrafya öğretmeni): "bir alana gittiğimizde o alanın jeoloji, jeomorfoloji, flora, vb. gibi gözlemliyorduk ama ..fauna benim hiç dikkatimi çekmiyordu. .yaban hayatının farkına vardım ve bu bana ... kazandırdığı en güzel şey. ... Seher vaktinde yaptığımız kuş gözlemleri .. faunanın farkına vardım ..."

R31YÖ: "...Olan bilgilerimin tazelenmesine ve farklılıklarımın artmasına neden oldu... bilinçlenmemizi sağladı. Almış olduğumuz tecrübenin, mesleki anlamda bizi motive edeceğine inanıyorum."

Çevre ve Doğa eğitimlerinde kaydedilen bilgi düzeyinin artışına dair benzer bulgulara Güler (2009) ve Keleş ve ark. (2010) da dikkat çekilmektedir. Katılımcıların eğitim konularından hangilerinin en fazla ilgilerini çektiğini, hangilerinin kendilerinde iz bıraktığını veya kalıcı etki bulunduğu Tablo 2'den çıkarmak mümkündür. Bu etkinin temelini ve nasıl oluştuğunu anlamak için ise serbest ifadelerin değerlendirilmesini gerekmektedir.

Tablo 4'deki görerek, dokunarak, hissederek öğrenmeye elverişli temalar olduğu bilinen 5, 6 ve 7 no'lu temalarda ifade edilen gözlemlerin katılımcı tarafından iyi öğrenildiğini, eğitimin kendilerine sağladığı bu kalıcı öğrenmeyi ve öğrenmedeki başarıyı çoğunlukla "görerek, dokunarak vb. öğrendik" şeklinde açıkladıklarını görmekteyiz.

R34iç: "Biyolog olduğum için görerek öğrenmek benim için çok önemli, teoriden çok görerek öğrenmek daha kalıcı."

R12SY: "Fauna ve flora elemanları hakkında doğrudan kendimiz görerek ve gözlemleyerek bilgi sahibi olduk. Örneğin, sabahın erken saatlerinde bir kuzgunun doğal alanındaki yaşayışına şahit olduk; bunun unutulmaz bir bilgi edinme yolu olduğuna inanıyorum." 
R12MO: "Örneğin bir kanyonun ne olduğunu oluşumunu okuyarak değil de içinden geçerek, yaşayarak, bakarak ve görerek öğrendik."

R23OBS: "Yaparak yaşayarak öğrenmek çok daha kalııı bir etki sağlıyor."

R34FK: “...buradaki her şeyi, bitkileri kalıı bir şekilde öğrendim. Eskiden Latince isimleri ezberliyorduk. Burada.. görerek öğrendik."

R12iNY: "Buraya geldiğimde bitki tanımada güçlük çekerken, şimdi kekik gibi bazı bitkilere dokunarak kokusundan ayırt edebiliyorum."

R31SB: "Buradan ayrlırken, bir kere fen bilgisi dersinin mutlaka doğada görerek öğretilmesi gerektiğini anladım. Çünkü biz bu eğitimde her şeyi görerek öğrendik. Örneğin bir ağacın dibine gittik. Bu ağacın Karaçam olduğunu, özeliklerini direkt ona dokunarak öğrendik."

R12MO:" Doğanın kendisini doğrudan gözlemlemek kesinlikle bambaşka bir öğrenme yöntemi ve akılda kalıcı. Örneğin, biz alanda saçlı meşeyle kermes meşesini aynı alanda görerek birbirinden ne kadar farklı olduğunu gözlemlememiz onca kitabi bilgiden daha değerliydi. Milli Eğitim Bakanlığının şu anda uygulamaya çalıştığı sistem de bu aslında; yaparak-görerek öğrenme.... Okullarımızda da bu sisteme derhal geçmemiz gerekiyor, diye düşünüyorum"

R11MÖ: "buradaki eğitimde gördügüm pek çok şeyi okulda teorik olarak gördüm diyebilirim. .Ama burada çok daha farklı olarak görselliğe önem verildi. Birebir, yerinde yapılan gözlemler ve kayıtlar bu eğitimin akılda kalıcı olmasını sağladı."

Röportajının "ileride öğretmenlik yaparken, burada öğrendiğiniz bilgileri kullanabilecek misiniz? Şeklindeki sorusuna R21AK ve R21ÇK tarafından birlikte verilen cevap: "....gerçekten görerek daha iyi öğreniliyormuş. Burada öğrendiğimiz bitki ve hayvan türlerini kullanacağız. Çok yararlı oldu."

IDE ile kazanılan bilgilerin gerçekten kalıcı ve kullanılabilir olup olmadığına dair sorgulama ise üçüncü bir anket (izleme) çalışması ile yapılmış, böylece nitel sonuçlar nicel yolla da denetlenmiştir. İzleme anketinde katılımcıların \%98,5' i doğa eğitim projeleri hakkında birçok arkadaşı, meslektaşı ve öğrencisine bilgi verdiğini ve katılımlarını teşvik ettiğini belirtmiştir. "Sizin tavsiyeleriniz sayesinde bir arkadaşınızın/öğrencinizin, vb. herhangi bir doğa eğitim programına katıldı mı?" şeklinde sorulan soruya ise katılımcıların yaklaşık \%47'si evet, \%15'i hayır ve \%38'i de bilmiyorum cevaplarını vermiştir.

\subsection{IDE Doğa Projelerinin Yaygın Etkisine iliş̧kin Bulgular}

IDE projelerinde proje amaçlarından birisi de katılımcıların elde ettikleri kazanımlar yardımıyla başka proje, seminer ve diğer doğa tabanlı etkinlikleri düzenleyebilme istek ve kabiliyeti oluşturma olarak belirlenmiştir. Bu kapsamda Tablo $5^{\prime}$ de projenin yaygın etkisine ilişkin betimsel veriler sunulmuştur.

Tablo 5

Katılımcının IDE Proje Sonrası Herhangi Bir Doğa Eğitim Programına Etkinlik Bazında Yaptığı Katkı*

\begin{tabular}{|c|c|c|c|c|}
\hline \multirow[t]{2}{*}{$\begin{array}{l}\text { Katılımcının IDE Projesi sonrası herhangi bir doğa eğitim } \\
\text { etkinliğin katkı sağlama durumu }\end{array}$} & \multicolumn{2}{|c|}{$\begin{array}{c}\text { Katkı var/yok } \\
\%\end{array}$} & \multirow{2}{*}{$\begin{array}{c}\text { Katkı } \\
\text { yok } \\
\%\end{array}$} & \multirow{2}{*}{$\begin{array}{c}\text { Katkı } \\
\text { var } \\
\%\end{array}$} \\
\hline & Var & Yok & & \\
\hline Öğrencilerime hitabeden etkinlik/etkinliklerim oldu & 42,6 & & - & \\
\hline Sosyal gelişime yönelik faaliyet katkım oldu & 19,1 & & - & 63,2 \\
\hline
\end{tabular}


Öğrencilerime ve sosyal gelişmeye yönelik faaliyet katkım oldu Katkı sağlayamadım/ uygun fırsat bulamadım Toplam
1,5

$\begin{array}{llll} & 36,8 & 36,8 & - \\ 63,2 & 36,8 & 36,8 & 63,2\end{array}$

Tablo 5'deki “*” işareti verilerin izleme anketlerinden toplandığını göstermektedir.

Anketlerde "Projenin ardından doğa eğitimi veya doğa ile ilgili herhangi bir etkinlik düzenlenmesine katkı sağlayabildiniz mi?" sorusuna katılımcıların \% 63,2'si evet cevabı vermiştir (Tablo 5). Hâlbuki nitel verilerde bu oran, yani "burada öğrendiklerimi orada uygulayacağım,... yapmayı düşünüyorum" tarzındaki ifadeler bu oranın sadece $1 / 3^{\prime}$ i kadar olup toplam katılımcının \% 21,1'i civarındadır. Proje ile katılımcıların doğa eğitim çalışmalarında kullanabilecekleri materyaller de sağlanmış ve bunların eğitim çalışmalarında kullanılması istenmiştir. Bu durumun sorgulanması amacıyla sorulan "Proje kapsamında edindiğiniz bilgi, doküman ve örnek materyalleri derslerinizde ya da eğitim çalışmalarınızda kullanıyor musunuz?" sorusuna katılımcıların \%91,2'si evet yanıtı vermiştir. Katılımcıların \%96,5'i de proje ile edindiği örnekleri meslektaşları ile de paylaşmışlardır.

Tablo $5^{\prime}$ de elde edilen nicel verileri destekler nitel verilere de görüşme ve serbest izlenimlerden elde edilen dokümanlar üzerinden ulaşmak mümkündür. Bu amacın ne ölçüde gerçekleştiğini gerek röportaj gerekse serbest ifadelerden çıkarmak mümkün olmaktadır. Görüşme ifadelerinden istek, katılımcıların özgüven artışları ve paylaşma niyetleri ortaya çıkmıştır. Bu ifadelere örnek olarak aşağıdaki görüşme metinleri örnek verilebilir. Bunlar;

S12MD: "Okuluma döndügümde kamp dönemindeki çalışmalarımızı okul yönetimi öğretmenleri ve öğrencilerimizle etraflıca paylaşıp, "Okulumuz içinde doğa koruma adına neler yapabiliriz?" sorusuna cevap arayacağız."

S12EB: "Eminim ki bugünden sonra... kamp boyunca edindiğimiz .. bilgileri bugün arkadaşlarımla ve hocalarımla yarınsa öğrencilerimle paylaşırken sizleri şükranla anacağım."

Proje katılımcılarının bu alanların tanıtımına katkı sağlayıp sağlamadıklarının belirlenebilmesi amacıyla izleme anketinde yer verilen "Arkadaşlarınıza eğitim alanlarımızı görmeleri yönünde bir tavsiyeniz oldu mu?" şeklinde sorulan bir soruya katılımcıların \%97'si evet cevabını vermiştir (Oğurlu ve Alkan, 2012).

Katılımcılar eğitimleri sırasında doğal korunan alanların canlı birer laboratuvar olduğunu gördüklerini ve eğitim için önemli fırsatlar sağladığını söylemektedirler. Ardından da bu fırsatı görevli oldukları okullarda kullanıp öğrencilerini doğada eğitmenin yollarını arayacaklarını ifade etmektedirler.

R11AE: "Canlı bir laboratuvarda hissettim kendimi. Malzemesi bol ve çok geniş bir laboratuvar"

S12ŞB:" Doğa laboratuvarında bakıp da görmediğimiz, bakıp da ...bilmediğimiz ne de çok şey olduğunu anladım."

R12SY.: "Doğa kesinlikle çok büyük bir laboratuvar. .. burada hemen her gün şahit olduk."

R22ZK: "Bir coğrafyacının laboratuvarı tabiattır" diye biliyorum. Burada benim için gerekli olacak çok önemli kazanımlar elde ettim."

R21ÇK: "Coğrafya ile ilgili derslerde zaten doğa bir laboratuvardır. Kesinlikle doğaya çıkmak gerekir." 
R12FE: “... doğayı doğa laboratuvarlarında öğrenmek, .... öğrencilere bir şeyler öğretmenin en iyi yolunun, onun yerinde öğretilmesi olduğunu öğrendik."

Proje kapsamında katılımcıların geliştirilmesini istedikleri ana yön olan oyun ve drama etkinliklerine dair yapılan sorgulamaya göre katılımcıların $\% 48,6$ 'sı proje sırasında öğrendikleri doğa oyunları ve drama uygulamalarını öğrencileri ile birlikte tekrarladıklarını söylemektedir. (Alkan ve Oğurlu , 2014).

\subsection{IDE Doğa Projelerinin Yeterliliğine İlişkin Bulgular}

Katılımcılara göre IDE Projelerinin yeterliliğinin ne düzeyde olduğuna dair bir değerlendirme yapılmak istendiğinde yine nicel ve nitel verilere birlikte bakmanın faydalı olacağı düşünülmüş ve önce anket sonuçları sonra da röportaj ve serbeste ifade metinleri incelenmiştir. Birinci ve ikinci anket çalışması bulgularına göre geniş katılımlı bir proje ekibi ve eğitmen tarafından belirlenen projenin içeriği, eğitim konuları ve eğitim alanlarının yeterliği hakkında katııımcının görüşüne başvurulduğunda IDE projelerinin katılımcılar tarafından drama ve oyunlar dışında yaklaşık \% 86-90 oranında beğeni ile karşılandığı görülmüştür (Tablo 6).

Tablo 6

IDE Projelerinin Muhtelif Açılardan Yeterliliğine Dair Katılımcı Görüşü*

\begin{tabular}{lcc}
\hline \multirow{2}{*}{ Göstergeler } & \multicolumn{2}{c}{ Seçenekler (\%) } \\
\cline { 2 - 3 } & Yeterlidir & Yetersizdir \\
\hline Eğitim programı içeriğinin uygunluk ve yeterliliği & 86,2 & 13,8 \\
Eğitmenlerin uygunluk ve yeterliliği & 90,6 & 9,4 \\
Arazi uygulamalarının yeterliliği & 89,7 & 10,3 \\
Sunulan görsel materyallerin yeterliliği & 88,7 & 11,3 \\
Programda yer verilen oyunların yeterliliği & 58,6 & 41,4 \\
\hline
\end{tabular}

Tablo 6'daki “*” işareti verilerin ikinci anketlerden elde edildiğini göstermektedir.

Eğitim projesi içeriği geniş katılımlı olarak proje personeli ve eğitmenlerce belirlenmiş; katılımcılardan alınan geri beslemelerle de sürekli revize edilmiştir. Katılımcıların çoğu sunulan içeriği yeterli bulmuşlardır. Katılımcılara "Beklentileriniz bazında proje içeriğini yeterli buldunuz mu?" şeklinde soru sorulmuştur. Bu soruya verilen cevaplardan aşağıdaki görüş metinleri örnek verilebilir. Bunlar;

R12TÖ: "Evet, yeterli buldum... Çünkü doğa içerisinde "görmek" ile "bakmak" arasındaki farkı öğrendiğimi düşünüyorum."

R31TÇ: "Örneğin bir bitki ve taşın ayrı uzman tarafından anlatılması çok etkileyiciydi. Eğitimin bu derece profesyonel olacağını düşünmemiştim, beni gerçekten çok etkiledi"

Katılımcıların yaklaşık \%91'i eğitmenleri yeterli olarak görmektedir. Buna, eğitmenlerin yeterliliği ile ilgili ifadeler örnek verilebilir. Şöyle ki;

R33HÇ: "Projede her şey çok planlıydı. Eğitmenlerimizin de bilgi düzeyi çok iyiydi."

S13HM: "Gidilecek yerlerin iyi seçilmesi, akademisyenlerin samimi ilişkileri ve bilgilerini katılımcılara en iyi şekilde sunmaları program süresince etkileyici unsurlardı."

R21TY: "Hocalarımız ve burada eğitim veren arkadaşlar çok deneyimli. Sıcak cana yakın, tevazu sahibi insanlar. Yani her sorumuza cevap verdiler, sıkılmadan... 
S12MG: "Hocalarımızın, bu bir haftalık eğitim boyunca gözlemlediğim azim ve heyecanları ayrıca beni oldukça etkiledi";

S13CS: "Bütün hocalarımız çok çabalıyordu. Ve bize yaklaşımları, bize verdikleri değer ve bizimle olan ilgi ve alakaları..."

S13NOT:" Hocamızın organizasyon yeteneği ve iletişim gücü, uzman ve asistanların olağanüstü sorumluluk duyguları ve eğitimcilerin etkili sunumları harmanlanınca bize mükemmel bir..yaşattı";

S13MKÖ: "Böyle bir proje ile bize harika imkânlar sunan eğitmenlerime, ... teşekkür ediyorum."

Buna karşılık, az oranda $(\% 9,4)$ bazı alanlarda eğitmen eksikliği hisseden katılımcılar da olmuştur. Eğitmen eksikliği ile ilgili örnek görüş metinleri katılımcılar;

R34GT: "Coğrafya ile ilgili bir eğitmenin olması daha da bir artı kazandırır diye düşünüyorum." diyerek ifade etmiştir. R21ÇK ise: "projede coğrafya bölümünde olan bir hocamız olsa fena olmazdı." demektedir.

Katılımcıların \%9'lu bölümü ise eğitmenlerin akademik bir yaklaşımdan biraz uzaklaşarak özellikle ilköğretim öğrencilerine konunun anlatılabilmesi ölçeğinde bir yaklaşım belirlemelerinin gerekliliğini ifade etmişlerdir.

R13YÇ: "...hocalarımız çok iyi, her şeyi çok iyi biliyorlar. Ama çok fazla şey anlatmaya çalışıorlar."

IDE projelerinde katılımcıların yaklaşık \%90'ı arazi uygulamalarını yeterli bulmuştur (Alkan ve Oğurlu, 2014)

Katılımcılara yöneltilen "Katılımcılar ve proje personeli ile tekrar bir araya gelmek ister misiniz?" sorusuna deneklerin \%95,6'sı kesinlikle evet cevabı vermiştir. Katılımcılarda tekrar katılma isteği uyandıran etmenler yapılan nitel değerlendirmeyle analiz edilebilmektedir. Mesela;

R13CS: "Eğitmenlerimizin-hocalarımızın yaklaşımı...çok sıcaktı, Yani, hiç mesafe yoktu, olsa belki bu kadar kaynaşamazdık."

R12FE: "okulda bir amfidesiniz ve çoğu zaman kafanıza takılan her şeyi soramıyorsunuz. buraya geldiğimizde ise hocalarımız bizlere her şeyi sorabilirsiniz dediler."

R12FE: "Ben ilk ve ortaokulda hiç araziye çıkmadım, bizim öyle sınıfa doğadan örnekler getiren hocalarımı olmazdı."

R34MM: "Hocalarımızla tüm etkinlikler sırasında beraberdik. Hocalarımız konularını anlatırken hemen arka planda o konunun başkahramanları olan bitki, hayvan, vb. objeleri görmek çok güzeldi."

S11AC: “... ben bu etkinlikten büyük zenginliklerle ayrıllyorum.... başta eğitmenlerimizden aldığımız bilgiler olmak üzere ... değerli hocamızın deneyimleri..."

Proje yeterliliğini değerlendirmeye yarayacak olan yukarıda belirtilen hususlarla birlikte ikinci anket uygulamasında katılımcılara "Eğitim projesi beklentilerinizi karşıladı mı?” "Bu proje doğaya bakışınızı ve bilgi düzeyinizi değiştirdi mi?" şeklinde sorular da yöneltilmiştir. Katılımcıların \%69'u tamamen, \%29'u orta derecede ve \%2'si de biraz diyerek beklentilerinin karşılandığı şeklinde cevaplar vermiştir (Tablo 7). 
Tablo 7

Projenin Katılımcı Beklentilerini Karşılama Açısından Yeterliği *

\begin{tabular}{|c|c|c|c|c|}
\hline \multirow{2}{*}{ Sorulan sorular } & \multicolumn{4}{|c|}{ Seçenekler** (\%) } \\
\hline & 1 & 2 & 3 & 4 \\
\hline Eğitim Programı beklentilerinizi tamamen karşılamaya yetti mi? & - & 2,0 & 29,0 & 69,0 \\
\hline $\begin{array}{l}\text { Eğitim programı doğaya bakışınızı ve konuyla ilgili bilgi düzeyinizi } \\
\text { yükseltmede yeterli oldu mu? }\end{array}$ & - & 6,4 & 40,4 & 53,2 \\
\hline
\end{tabular}

Tablo 7' daki değerleri nitel yolla çözümleme yoluna gidildiğinde anket sonuçları açıklık kazanmaktadır. Mesela;

R13YÇ: "bu eğitim insanın doğaya karşı duyarlılığını arttıran bir şey, dolayısıyla insanın bakışı değişiyor. Yani, daha önce aklıma gelmezdi, ama şimdi etrafta dolaşırken bu ağaç ne, bu kuş ne deyip, çevreyle ilgili bir şeyler sorguluyorum. Bu daha önceden yaptığım bir şey değildi. Öğretmen olduğumda, bunu öğrencilere yansıtabileceğim."

S11Ti: "Burada öğrencilerime aktaracak çok bilgi edindim. Doğaya bakış açım değişti."

R31ÇB: "Biz doğaya ...bilinçsizce bakıyormuşuz. Eğitimde öğrendiklerimizle doğaya bakış açımız değişti."

R23NÇ: "...Daha bilinçli gözle bakmaya başladım. Artık gördüğg̈m bir ota bile ot diyerek geçemeyeceğim."

R34ÖA: "doğayı sevdiğim halde doğanın içerdiklerinden çok da haberdar olmadığımı anladım. Artık, Doğaya daha geniş bir açıyla bakılabilecek ve daha detaya inebileceğim."

R21ÜB: "Doğaya olan bakış açım değişti....Milat gibi oldu benim için."

\subsection{Doğa Eğitimine Katılım Durumuna Göre IDE Eğitim Alanına Katılımcıların}

\section{Görüşüne Iliş̧kin Nitel Bulgular}

Çalışma kapsamında ayrıca, daha evvel proje eğitim alanlarını görmüş katılımcılar üzerinde IDE proje etkinliğine katıldıktan sonra bu alanlara bakışlarının değişip değişmediği de araştııı ış̧tır. Proje bitiminde bu katılımcılardan anılan alanlara bakışlarını proje başlangıcı ile kıyas etmeleri istendiğinde, gittikleri bu alanları flora, fauna, jeolojik yapı, farklı ekosistemler, kırsal toplumlar ve peyzaj değerlerini, projeden önce yeterli ölçüde fark ve idrak etmedikleri dolayısıyla bu alanların katılımcıların gözünde genellikle sıradan alanlar olduğu anlaşılmıştır.

Eğitim alanlarını ilk defa gören Proje katılımcıları eğitim alanı olarak kullanılan korunan alanları çok beğendiklerini her fırsatta dile getirmişlerdir. "Eğitim alanlarımız içerisinde unutamadığınız ve fırsat bulduğunuzda tekrar ziyaret etmek istediğiniz yerler var mı?" şeklinde sorulan soruya katılımcıların tamamı "evet" cevabı vermişlerdir. Hatta katılımcıların \%75'i bu alanları ilk fırsatta öğrencileri ile birlikte tekrar gezmek istediklerini ifade etmişlerdir. Çok sayıda katılımcı birbirine çok benzeyen ifadelerle etkinlik alanlarının yer aldığı Isparta yöresinin umduklarından güzel bulduklarını söylemekte, bu yörede bir eğitime katılmaktan 
duydukları memnuniyeti dile getirmekte ve bu alanları tekrar görebilmeyi istemektedirler. Örnekler:

R21ÇK: doğal alanları gezerken Isparta'da ne kadar da fazla ... R21TY: “ Isparta doğal güzellikleri bakımından çok zengin. .. bu kadar olduğunu düşünmüyordum."

R34 GY: Çok güzel bir bölge, ormanları çok; biyoçeşitlilik çok fazla.

Beklentilerimin çok üstünde." R34 PA: "Bu kadar yeşil olduğunu bilmiyordum"

R31ÇB: "Isparta'nın doğasının bu kadar güzel olduğunu bilmiyordum." R33 HiU : "Çok güzel."

R13SM. " ..buraların ne kadar güzel olduğunu ancak görenler bilir.

S12ART: “... Isparta'nın ve yöresinin ne kadar güzellikler barındırdığını hayretle gördüm."

R34 SO: "Isparta'nın doğasının bu kadar zengin olduğunu bilmiyordum."

S12SY: “... bu denli zengin fauna, flora ve jeomorfolojik yapı..."

R13NB: . O fosil tepeleri.. aldığımız örnekler.. çok güzeldi; tekrar görmek isterim."

Yukarıdaki katılımcı ifadeleri etkinlik alanlarını oluşturan doğal sahalarda yürütülen eğitim faaliyeti sırasında katılımcının rahat, mutlu ve keyifli olduğuna işaret etmektedir. Bunun eğitim kalitesinin artması yönünde etki ettiği düşünülmektedir. IDE projeleri için seçilen eğitim alanlarının bu projelerin tercih edilişi ve eğitimin katılımcı üzerindeki olumlu etkisi dolayısıyla isabetli birer seçim olduğunu başka araştırmaların sonuçları da göstermektedir (Oğurlu vd., 2010; Oğurlu ve Alkan 2012; Oğurlu vd., 2013).

\subsection{IDE Doğa Projelerinde Çadır Kamplarına İlişkin Nitel Bulgular}

IDE projeleri katılımcıların doğa konusundaki bilgi düzeyi artışına ivme kazandırmış ve bu düzeyin kalıcı hale gelmesini ve davranışa dönüşmesini sağlamıştır. Bunda en etkili faktörlerden birinin de TÜBiTAK desteğiyle yürütülen doğa eğitim projeleri arasında yalnız IDE projelerine mahsus bir uygulama olan her eğitim döneminde en az 2-3 gün çadırlı kamp kurma uygulamasının olduğu düşünülmekteydi (Oğurlu ve Alkan, 2012). Nitekim nitel veriler de güçlü bir şekilde bunu desteklemişlerdir.

R23NO: "Bu kamp sayesinde çok şeyöğrendim."

S12MD: "...kampta; doğadaki ot veya çalı deyip geçtiğimiz birçok türün aslında şifalı bitkiler olduğunu... anladım. Kamp boyunca ekip çalışmasının güzelliğini yaşadım."

S12KA: "kamp ortamı.. bize çok şeyler kazandırdığı muhakkak. Kim derdi ki gece yarısı buz gibi kaynak suyunda yıkanacağımızı ve böylesine hoş bir ortamda..."

S12HT: "doğayı, kitaplardan değil de bizzat içinde tanımak arzusunda olan birisi olarak, bu eğitimden azami derecede yararlandığımı belirtmeliyim. Özellikle üç günlük kamp serüvenimiz, hayatımda .. yaşadığım en ..."

S12MG: “....kamp. .. Birçok bilgi öğrendik. .. ama benim için en önemlisi bir coğrafya öğretmeni olarak bunca yıldır teorik olarak bildiğim ve .. aktardığım bu bilgilerin.. pratiğe dönüşmesiydi" 
S12AA: "Bu eğitimden elde ettiğim en güzel şey, tabiatta .. kamp yaparken .. kendimi ...tanıma fırsatı bulmamdır."

Kampımızın size bir şeyler kattığını düşünüyor musunuz? Sorusuna karşı katıımcıların örnek görüş metinleri şöyledir;

R21ÜB: “ Doğa denilince aklıma hep kuşlar, deniz, göl gelirdi. Şimdi ise doğanın çok farklı olduğunu gördüm... doğaya olan bakış açım değişti."

S13MKÖ: "Sonuç olarak, bütün güzelliğiyle bir kamp geride kaldı ve ben ... Gelirken kafamda oluşan soruların cevaplanmış olduğunu ve kendimi.. gözlemlenen konularda yorum yapabilecek düzeyde hissediyorum."

Öğretmenlik yanı sıra izci liderliği de yapan katılımcıların ifadeleri ise şöyledir:

R23YK: “...yıllardır doğayla iç içeyim. 20 yıldır sürekli kamp yapıyorum... izci liderliği... kamp anlamında bilmediğim pek bir şey yoktur. .. Kamp gayet iyiydi, .. Bu konuda da güzel şeyler gördüm."

R31MKY: “... kampta her gün yeni bir şeyler ögrreniyoruz...gece...yıldız gözlemleri, gökyüzü gözlemleri, gündüz ... kuşlar doğadaki bitkiler ..(bunları) öğrencilerimize verebiliriz, artık. Bu konudaki açığımızı kapatmış olduk bu proje sayesinde."

\subsection{IDE Doğa Projelerinin Geliştirilmesine Yönelik Nitel Bulgular}

IDE projelerinin katılımcılar tarafından drama ve oyunlar dışında yaklaşık \% 86-90 oranında beğeni ile karşılandığı görülmüştür (Tablo 6). Oyunların beğeni derecesi ise bunların hayli gerisinde $(\% 58,6)$ kalmıştır. Oyun ve dramaların yetersizliği R34UÇ kodlu ve projenin tamamı hakkında mutlak olumlu kanaat belirten katılımcının ifadesinde bile bir istisna olarak kendini göstermektedir.

R34UÇ şöyle demektedir: " ... .çok başarılı olduğunu tüm samimiyetimle söyleyebilirim. ... müthiş bir ekip ve ... çok güzel bir uyum içerisinde. ... Bütün katılımcılar eğitimci hocalarımızı yakından gözlemledik. Onların o birlikteliği ve fedakârlıklarının bizlere çok iyi yansıdığını düşünüyorum. ... her şey yolundaydı. Ama drama eğitimleri biraz arttırılabilir. Onun haricinde her şey yerli yerindeydi."

Bu durum değerlendirilerek daha sonraki IDE projelerinde (IDE-4,5,6) drama uzman ve formatörlerine daha fazla yer verilerek onların yardımıyla drama ve oyunları artırma ve çeşitlendirme yoluna gidilmiştir (Oğurlu vd, 2010).

\subsection{IDE Doğa Projelerinin Sosyal Sorumluluğu Üzerine Nitel Bulgular}

İdeal bir doğa eğitiminde katılımcıların sorunlar üzerinde çalışması, flora, fauna, ekosistemlerin sorunları yanı sıra başta yerel topluluklar olmak üzere toplum üzerinde de bu sorunları eğilmesi ve uygulamalar yapması gerekmektedir. IDE projelerinde bu yapılmaya çalışılmış ve oba düzeniyle hareket eden katılımcılar yerel halkla temasa getirilerek onlarla görüşmeleri ve kayıtlar almaları şeklinde etkinlikler yapılmıştır. Söz konusu kayıtlar

URL-4 adresinde Köy Röportajları başlığıyla verilmiştir. Bunlar incelendiğinde katılımcıların, aynen doğal varlıklar konusunda olduğu gibi doğal hayatın sakinleri olan kırsal nüfus ve sorunları hakkında da farkındalık kazandığı görünmektedir. 


\section{SONUÇ, TARTIŞMA VE ÖNERILER}

IDE proje eğitim etkinliklerinin başında ve sonunda katılımcıların doğa projelerine katıım tercihlerini etkileyen faktörler, proje eğitim programının kazandırdığı olumlu tutum ve davranışlar, proje eğitiminin yeterlilikleri, kamp faaliyetleri, projeyi takip eden dönemde katılımcının rol oynadığı yaygın ve etki topluma katkılarına yönelik görüşleri ve önerileri nicel ve nitel bulgular doğrultusunda değerlendirilmiştir.

Doğa eğitim projelerine katılımcı seçme süreci projenin önemsiz gibi görünse de sürdürülebilirlik açısından gözden kaçırılmaması gereken önemli bir ayrıntı ve proje yürütücüsü için bir kaygı kaynağıdır. Yürütücüler proje başlangıcından bitinceye kadar katılımcı seçiminde isabetli davranıp davranamadıklarını merak ederler. Bu bağlamda çalışmanın sorgulanabilir amaçlarından biri de katılımcı tercihlerini etkileyen faktörlerin belirlenmesi olmuştur. "Projenin ögrencilerime doğayı daha ayrıntılı ve bilimsel olarak anlatma fırsatı sağlayacağını düşünüyorum" önermesi, eğitim projelerine katılım kararında önemli bir yere sahiptir. Ayrıca, "Bitkisel ve hayvansal varlıkların yaşama ortamlarını daha iyi tanıma", "Yeni yerler görme düşüncesi", "Yaban hayvanları ve fauna hakkında daha ayrıntılı bilgiye sahip olma", "Flora, bitki türleri ve ağaçlar hakkında daha fazla bilgiye sahip olma", "Doğayla iç içe yaşayan yerel halkı daha iyi tanıma ve doğa-insan etkileşimi konusunda daha ayrıntılı bilgiye sahip olma" gibi önermelerin ifade ettiği etmenler de öğretmen ve aday öğretmenlerin IDE projelerine katılım kararında etkili olmuştur. "Boş zamanımı değerlendirme fırsatı sunması" önermesi ise en az kabul gören önerme olmuştur. Bu durum özellikle müstakbel doğa eğitim projeleri için eğitim programına ait içerik ve eğitim alanları belirleme konusunda yol gösterici olabilir (Oğurlu vd., 2010). Katılım kararında etkili olan faktörler içinde bitki ve hayvanları yetişme ortamlarıyla birlikte öğrenme ve edinilen bilgileri öğrencileri ile paylaşma isteği öne çıkmaktadır. Bu durum benzer bazı proje bulguları arasında da yer almaktadır. Bununla birlikte yeni insanlarla özellikle de doğaseverler ve bilim adamlarıyla tanışma, yeni yerler görme, doğayla iç içe yaşayan köylüleri daha iyi tanıma veya peyzaj gibi konularda bilgi edinme fırsatı sağlaması projeye katılım sebepleri arasında yer almaktadır.

Kavramsal bilgilerin sunulması ile yetinen bir doğa eğitiminin davranış oluşturma bağlamında başarıya ulaşması mümkün değildir. Buna karşılık, eğitimin doğada ve arazi çalışmalarıyla desteklenmesi edinilen bilgilerin davranışa dönüştürülmesi ve kalıcı olması bakımından önemli katkılar sağlamaktadır (Bartosh, 2003; Erten, 2003; Erten, 2004; Farmer vd., 2007; Güler, 2009; Kostova ve Atasoy, 2008; Ozaner; 2004). Sözgelimi S12MG kodlu katılımcı: "Bunca yıldır teorik olarak bildiğim birer metinden oluşan bilgilerimin adeta IDE boyunca ete kemiğe bürünerek hayat kazandı." demektedir. Bir diğer katılımcl (R11AE) ise; "... ve biz bunları sadece görmüş olmadık, öğrendik bir de. Şimdi artık, doğayı anlamlandırmak daha kolay bizim için." diyerek eğitim boyunca aldıkları bilgilerin hazmedilmiş olduğunu ve davranışa dönebileceğinin işaretini vermektedir.

Doğaya sadece biyoloji-ekoloji temelli bakmak ve bu iki disipline göre doğayı anlamaya çalışmak yeterli bir yaklaşım değildir. İnsan ve kültür de mutlaka bu yaklaşımın içinde olmalıdır (Okan, 2004). Bu kabulden hareketle geniş katılımlı ve multidisipliner bir proje ekibi oluşturulmuştur. Proje kapsamında doğanın farklı kollarında uzman birçok bilim insanı ve doğa dostu bir araya getirilmiş ve tüm eğitim dönemi boyunca katılımcılarla aynı ortamları paylaşmaları sağlanmıştır. Katılımcılardan alınan dönütlere göre proje ekibinin sürekli olarak ekiple birlikte hareket etmesi hem samimi ve paylaşımcı bir ortamın ortaya çıkmasına hem de katııımcıların üst düzeyde bilgilenmelerine imkân sağlamıştır. Korunan alanlarda yürütülen bazı projelerde kaynak yöneticilerinin sürece yeterince dahil olmayışları, eğitim projeleri kapsamında eleştirilen bir husus olarak dikkat çekmektedir (Okan, 2004). IDE projeleri bu yönüyle de oldukça farklı bir perspektif çizmiştir 
Eğitimde "Merak et!, Öğren! ve Uygula! Modeli" kullanılmıştır. Mesela volkanizmanın öğrenilmesi için volkanizma faaliyetine sahne olmuş bir alana gidilmekte, ancak bundan hiç bahsedilmeyerek önceden planlanmış bir oyun kapsamında katılımcıdan oradaki gölde taş sektirmeleri istenmektedir. Attığı taşın suda batmayıp yüzdüğü gören katılımcı taşa dikkat etmekte, taşın gözenekli ve hafif bir dokuya sahip olduğunu görmekte, bunun açıklaması istendiğinde ise böyle bir durumun ancak taşın oluşumu sırasında içinde gaz püskürmesi sonucu oluşabileceğini ve dolayısıyla durdukları arazinin ve oradaki taşların bir volkanizma olayı ile meydana geldiği sonucuna ulaşabilmekte, bundan sonra ise etrafa göz gezdirerek krater gölü ve volkan konisini kendisi keşfetmekte, daha sonra ise volkanik bir arazinin kayaçları ve onlar üzerinde gelişen floranın özelliklerini gözlemlemeye başlamaktadır. (bkz: URL-5).

R11MO kodlu katılımcının şu ifadesi '...bu eğitim metodu, kesinlikle daha akılda kalıcı, daha uygulamaya yönelik. Ve edinilen tecrübe kesinlikle çok daha fazla... edindiğim bu bilgi ve tecrübeyi öğrencilerime aktarmaya çalışacağım." gibi katılımcılara ait benzeri birçok ifade modelin başarısı ve projenin amacına ulaştığına işaret etmektedir.

IDE Projeleri öğretmen ile öğretmen adaylarının doğa konusundaki bilinç ve olumlu tavır gelişimine hatırı sayılır ölçüde katkı sağlamıştır. Bu katkının ağırlığı nicel ve nitel araştırma teknikleri uygulanarak denetlenebilmektedir. Her bir proje sonrası yapılan anket çalışması (İzleme anketleri) ise bu katkının kalıcı ve projenin yaygın etkisinin güçlü olduğunu göstermektedir.

Katılımcılar doğal korunan alanların canlı birer laboratuvar olduğunu ve eğitim için önemli fırsatlar sağladığını görmüşler ve gittikleri yerlerde yapacakları ders ve eğitim etkinliklerinde bu imkândan nasıl yararlanacaklarını öğrenmişlerdir. Nitekim Katılımcıların çoğu ifadelerinde eğitim sırasında zihinlerinde bu konuda oluşan proje fikirlerinden veya planlarından bahsetmişlerdir. İzleme anketi sonuçlarının katılımcıların bu projelerinin şu veya bu ölçüde gerçekleşmeye başladığını göstermesi, IDE projelerinde proje hedeflerine ulaşıldığının da göstergesidir. Hatta izleme anketlerinde "Projenin ardından doğa eğitimi veya doğa ile ilgili herhangi bir etkinlik düzenlenmesine katkı sağlayabildiniz mi?" sorusuna katılımcıların \% 63,2'si evet demesine (Tablo 5) karşılık nitel verilerde bu oranın, yani "burada öğrendiklerimi orada uygulayacağım,... yapmayı düşünüyorum " tarzındaki ifade frekansının toplam katılımcının ancak $1 / 3^{\prime}$ ine (\% 21,1'i) ulaşması IDE programlarına katılanların gittikleri yerlerde bir doğa eğitim etkinliğine önceden düşündüklerinden daha fazla katkı sağlama fırsatı bulabildiklerini veya IDE eğitiminde kazandıkları formasyonun hayli işe yaradığın göstermektedir.

Proje içeriği, eğitim etkinlik konuları ve alanları katılımcılar tarafından beğeni ile karşılanmıştır. Eğitmenlerin etkinli dönemi boyunca katılımcılarla birlikte olması, bir ekip ruhunun ortaya çıkmasını sağlamış, iletişim ve etkileşimi güçlendirmiştir. Bu sayede katııımcıda önemli düzeyde bilgi artışı kaydedilmiştir.

Etkinlik alanlarının katılımcı tarafından sevilip beğenilmesi eğitim faaliyeti sırasında katılımcının rahat ve memnun olması eğitimin katılımcı üzerindeki olumlu etkisini arttırmıştır. Eğitim söz konusu olduğunda eğitimin eğitilenlerin duygu dünyasını da etkilemesi halinde daha başarılı olacağı, yani eğitimin duygu temelinin de dikkate alınması gerektiği bilindiği için bu alanların özellikle sadece eğitsel anlamda değil duygu anlamında da katılımcıyı etkilemiş olması, etkinliklere ilgiyi ve aktif katılımı arttırarak ve kültürümüzde "Hatırda kalmaz, sadırda (gönülde, yürekte) kalır." deyimiyle işaret edilen bir olguya, yani eğitim sürecinde görülen ve duyulanların duygu temeline oturmasını sağlamış ve öğrenilenlerin kalıcılığını arttırarak eğitimin daha verimli olmasına yol açmıştır. 
"Katılımcılar ve proje personeli ile tekrar bir araya gelmek ister misiniz?" sorusuna deneklerin çok büyük kısmının $(\% 95,6)$ olumlu cevap vermesinde eğitmenlerin arazi kampları dâhil tüm proje süresi boyunca katılımcılarla birlikte olarak bir ekip ruhunun ortaya çıkmasını sağlamasının etkisi büyüktür. Bu durum eğitmen-katılımcı etkileşimi güçlendirmiş ve dolayısıyla eğitimin verimini arttırmıştır.

Katılımcılara kapalı mekânlarda hazır bilgiler sunmak yerine, orman, korunan alan, flora, fauna, jeoloji, peyzaj, ekoloji, iklim, kırsal yerleşimler, vb. birçok alanda pratik değere sahip bilgiler de kazandıracak uygulamalı eğitim programlarını doğa arazi şartlarında sunmak hem proje başarısını hem de katılımcı tatmin düzeyini arttırmıştır. Ayrıca, farkı kaynak değerlerine sahip doğal korunan alanlarda kamp yapmanın ve hava şartlarına göre en az 2-3 gün çadırlarda kalmanın katılımcıların kaynaşmasını kolaylaştırdığı gibi, ilgi ve konsantrasyonu da arttırdığı düşünülmektedir (Oğurlu vd., 2010). Nitel çözümlemeler de bunu göstermiştir. İyi planlanmış etkinlik programlarıyla arazi ve iklim şartlarından kaynaklanan zorlukların (kış mevsimindeki soğuk hava- karlı zemin dâhil) katılımcıların projeyi yaş ve cinsiyet fark etmeksizin sahiplenmesine engel oluşturmayacağı görülmüştür.

Projeler için eğitim etkinlik alanları olarak seçilen korunan doğal alanların flora ve fauna bakımından zengin kaynak değerlerine sahip olması; yapılan aktivite çeşitliliğini arttırarak proje içeriğini zenginleştirmeye yaramış ve ayrıca uygun kamp fırsatı sunması bakımından da katılımcılara önemli eğitim avantajları sağlamıştır. Bu alanların özellikle sadece eğitsel anlamda değil duygu anlamında katılımcıyı etkilemiş olması, yani katılımcı tarafından sevilmiş ve beğenilmiş olması etkinliklere ilgiyi ve aktif katılımı arttırarak eğitimin daha verimli olmasına yol açmıştır. Şu halde yeni yapılacak doğa eğitim projelerinde saha etkinlikleri için Isparta korunan doğal alanları gibi hem dağ-göl-orman gibi çeşitlilik arz eden ve hem de görsel yönden etkileyici alanların seçilmesi önerilebilir.

Eğitim etkinlikleri doğada gerçekleştirilen projelerde, edinilen bilgilerin davranışa dönüşmesinin kolaylaştığını ve daha kalıcı etkiler oluşturduğunu söylemek mümkündür. Doğayla bütünleşme sağlayan çadırlı kamp gibi uygulamaların bu etkiyi daha da güçlendirdiği görülmektedir. IDE projelerinde bu etki gözlenmiştir. Çünkü proje kapsamında her eğitim döneminde en az 2-3 gün çadır kamplarında konaklama yapılmıştır. Bu etkinlik türü ise öteden beri TÜBITAK'ın desteklediği doğa projeleri arasında sadece IDE projelerinde bulunmaktadır

Sonuç olarak çalışmanın bulguları ilgili alan yazını doğrultusunda değerlendirildiğinde, IDE Projelerinde şekillenen bu eğitim modeli kapsamında uygulanan aktif öğrenme yöntem ve tekniklerinin katılımcıların doğaya yönelik tutum ve bilinçlerini geliştirmede etkili olduğu ortaya çıkmıştır.

\section{TEŞEKKÜR}

Bu makale "Isparta Korunan Doğal Alanlarında Doğa Eğitimi (IDE) adıyla bilinen TÜBiTAK'ın destek sağladığı üç ayrı proje olan IDE-1(proje no 107B031), IDE-2 (108B015) ve IDE-3 (110B089)'ün verilerine dayanmaktadır. Başta TÜBiTAK' a ve bu projelerin yürütülmesi sırasında emek harcayan KTÜ Orman Fakültesi öğretim üyesi Dr. Ebubekir GÜNDOĞDU ile SDÜ Orman Fakültesi öğretim üyeleri Dr. Oğuzhan SARIKAYA, Dr. Hasan ALKAN, Dr. Mehmet EKER, Dr. İsmail DUTKUNER ve Uzman Süleyman UYSAL'a teşekkür ederim. 


\section{KAYNAKLAR}

Alkan H., Korkmaz M. (2009). An Investigation for socioeconomics problems in management of protected areas, II. Ormancllikta Sosyo-Ekonomik Sorunlar Kongresi, Isparta, s.13-22.

Arslan M. (1997). Changes in environmental awareness and environmental education, Education and Life, 23-26.

Ballantyne R., Packer J., (2002), Naturebased excursions: school students perceptions of learning in natural environments, International Research in Geographical and Environmental Education, 11, 218-236.

Atasoy, E. (2006). Çevre için eğitim çocuk doğa etkileşimi. Bursa: Ezgi Kitabevi.

Baş, T. ve Akturan, U. (2008). Nitel araştırma yöntemleri. Seçkin Yayınları, Ankara, 2008.

Benedict, F. (Ed.). (1991). Environmental education for our common future: A handbook for teachers in Europe. Oslo, Norway: Norwegian University Press

Berberoğlu, E, O., Güder, Y., Sezer, B. ve Yalçın-Özdilek, Ş. (2013). Sınıf dışı hidrobiyoloji etkinliğinin öğrencilerin duyuşsal bakış açıları üzerine etkisi, örnek olay incelemesi: Çanakkale, bilim kampı. Kastamonu Eğitim Dergisi, 21 (3), 1177-1198.

Doğan, M. (2007). Orta öğretimde çevre eğitimi. Türkiye Çevre Vakfı Yayını No: 178, Ankara, 59-68.

Erol, G.H. and Gezer, K. (2006). Prospective of elementary school teachers' attitudes toward environment and environmental problems, International Journal of Environmental and Science Educiation, 1(1), 65-77.

Murat Genc (2015) The project-based learning approach in environmental

education, International Research in Geographical and Environmental Education, 24:2, 105117, DOI: 10.1080/10382046.2014.993169

Güler, T. (2009). Ekoloji temelli bir çevre eğitiminin öğretmenlerin çevre eğitimine karşı görüşlerine etkisi, Eğitim ve Bilim, 34(151), 30-43.

Haktanır, G. (2007). Okul Öncesi Dönemde Çevre Eğitimi. Türkiye Çevre Vakfı Yayını No: 178, Ankara, 11-34.

IDE-1 (2007). IDE: Isparta Korunan Doğal Alanlarında Doğa Eğitimi Projesi. Proje Dokümanları, Proje no: TÜBITAK 107B031

IDE-2 (2008). IDE-II: Isparta Korunan Doğal Alanlarında Doğa Eğitimi Projesi II. Proje Dokümanları, Proje no: TÜBITAK 108B015.

IDE-3 (2010). IDE-3:Isparta Korunan Doğal Alanlarında Doğa Eğitimi Projesi III. Proje Dokümanları, Proje no: TÜBITAK 110B089.

Keleş, Ö., Uzun, N. ve Varnacı-Uzun, F. (2010). Öğretmen adaylarının çevre bilinci, çevresel tutum, düşünce ve davranışlarının doğa eğitimi projesine bağlı değişimi ve kalıcılığının değerlendirilmesi. Elektronik Sosyal Bilimler Dergisi, 9 (32), 384-401.

Kostova, Z. and Atasoy, E. (2008). Methods Of successful learning in environmental education, Egitimde Kuram ve Uygulama , 4 (1), 49-78.

Malone, K. and Tranter, P. (2003). Children's environmental learning and the use, design and management of schoolgrounds. Children, Youth and Environments, 13(2), 1-30. 
Noughton-Treves, L., Holand, M. and Brondon, K. (2005). The role of protected areas in conserving biodiversity and sustaining local livelihoods. Annual Review of Environment and Resources, 30, 219-252.

Oğurlu, I., Alkan, H., Unal, Y., Ersin, M.O. and Bayrak H. (2013). Contributions of environment and nature training to geography education: IDE projects case study / Cevre ve Doğa Eğitimlerinin Coğrafya Eğitimine Katkilari: IDE Projeleri Orneği, The 3rd Internatinal Geography Semposium-GEOMED 2013, Kemer-Antalya-Turkey, 2013, Symposium Proceedings, ISBN:978-605-62253-8-3 Pages 498-508.

Oğurlu, i., Alkan, H. (2012). Korunan Alanların Doğa Eğitimi Projelerindeki Yeri ve Önemi, III.. Ormancılıkla Sosyo-Ekonomik Sorunlar Kongresi, İstanbul Üniversitesi, Orman Fakültesi 18-20 Ekim 2012, İstanbul, Bildiriler Kitabı Cilt I, sayfa 1-7.

Oğurlu, İ., Alkan, H. ve E. Gündoğdu. (2010). Isparta korunan doğal alanlarında doğa eğitimi-ı: katılımcıların algı ve beklentileri, III. Ulusal Karadeniz. Ormancılık Kongresi, 20-22 Mayıs 2010, Cilt I, sayfa 144-152.

Ozaner F. S. ve Yalcin, G. (2000). Milli parklarda bilimsel çevre eğitimi, V. Uluslararası Ekoloji ve Çevre Sorunları Sempozyumu. (Ed. İlhami Kiziroğlu, Nelka İnanç ve Levent Turan), Ankara Alman Kültür Merkezi, 64-76. ilimler Dergisi www.esosder.org Bahar-2010 C.9 S.32 (384401) ISSN:1304-0278

Ozaner, F. S. (2004). Türkiye'de okul dışı çevre eğitimi ne durumda ve neler yapılmalı?, V.Ulusal Ekoloji ve Çevre Kongresi, 5-8 Ekim 2004 Taksim International Abant Palace, Abant İzzet Baysal Üniversitesi ve Biyologlar Derneği, Abant- Bolu. Bildiri Kitabı (Doğa ve Çevre), 6798, Biyologlar Derneği, İzmir

Palmberg, I, E. \& Kuru, J. (2001). Children and Nature. ATEE 26th Annual Conference: RDC 17: Enviromental Education

Payne, P. G. (2006). Environmental education and curriculum theory. The Journal of Enviromental Education, 37(2), 25-35.

Phenice, L. A. and Griffore, R. J. (2003). Young children and the natural world. Contemporary Issues in early childhood, Sage Journals, 4(2), 167-171.

Pitman, B. J. (2004). Project WILD. A summary of research findings 1983-1995 and 1996-2003. Project WILD National Office Council for Environmental Education, 1-28, US.

Shanely, S. D. (2006). Towards An Understanding of an Outdoor Educatıon Program: Listening To Participants' Stories. PhD Thesis, University of Florida, USA, 2006.

Soran, H., Morgil, I., Yücel, S.E. ve Işık, S. (2000). Biyoloji öğrencilerinin çevre konularına olan ilgilerinin araştırılması ve kimya öğrencileri ile karşılaştırılması, HU Eğitim Fakültesi Dergisi, 18, 128-139.

Tesch, R. (1990). Qualitative Research Analysis Type\& Software Tools. Routledge, Tylor\&Francis Group, Great Britain.

Vidich, A. J. (2008). Participant observation and the collection and interpretation of data. The American Journal of Sociology, 60(4), 354-360, 1955.

Yıldırım, A. ve Şimşek, H. (2006). Sosyal bilimlerde nitel araştırma yöntemleri. Seçkin Yayıncılık, Ankara. 
Yılmaz, A., Morgil, İ., Aktuğ, P. ve Göbekli, ì. (2002). Ortaöğretim ve üniversite öğrencilerinin çevre, çevre kavramları ve sorunları konusundaki bilgileri ve öneriler. HU Eğitim Fakültesi Dergisi, 22, 156-162.

Zanovello, I. (1999). Outdoor and Environmental Education Centres: A Case Study of Starthcona Park Lodge and Outdoor Education Centre, British Columbia, Canada. A Master Degree Thesis, Faculty of Envirnmental Design, The University of Calgary, Alberta

\section{İnternet Kaynakları}

URL-1: http://ide.sdu.edu.tr

URL-2: http://ide.sdu.edu.tr/index.php?page=katilimcigozuyleide

URL-3: http://ide.sdu.edu.tr/belgeler/gunluk_2008_03_subat.pdf

URL-4: http://ide.sdu.edu.tr/index.php?page=roportajlar

URL-5: http://ormanweb.sdu.edu.tr/ide/Albumler/idemayis/album/slides/IMGP0094.html 


\section{SUMMARY}

Shallow environmentalism and formal education programs, especially in developing countries including Turkey is insufficient and falls short of creating awareness and terminal behaviors for Nature. Nowadays nature training projects, IDE projects are among them, have been supporting by TÜBITAK offer great facilities for teachers which are the most important actors in the teaching aware of the environment.

IDE projects, Nature Training Projects in Isparta Natural Protected Areas (NPA's) were realized between the years 2007 and 2010 in eleven terms each of consist of 8-10 days A total of 247 participants of the projects were teachers of science, biology and geography or teacher candidates During the training course, an active learning model was used as "Wonder it-Learn it and Apply it. Participants stayed in a camp for 2-3 days to apply a variety of activities such as setting a camp, observing of wildlife, earth or sky

It has seen that using qualitative and quantitative approaches together in order to explain the results was favorable for studying reasons for preferences or motivations of participants.

The material of this study constitutes of forms of the interview documents in the web site. After evaluated data from interviews qualitatively, results were compared with the ones from quantitative techniques.

Three different surveys were realized by using form of the questionaries, the first one at the beginning of the training the second one at the end and the last after the courses (follow-up survey). While the first and second surveys applied were realized based on 203 surveys, for follow-up survey has realized a sampling sample

With multiple choices and graded questions were the 4 versioned Likert-type scales. In order to test the reliability of the test the Cronbach's alpha ( $\alpha$ ) coefficient (the alpha method) was used. The Cronbach's alpha value was calculated as 0.896 and the reliability of the test was detected to of high value.

In assessing applied relationship among the frequencies, priorities and varieties the SPSS program and the Mc excel software were used. The cross-table and the chi-square analysis were benefitted from for the detection of differences and relationships among the variables

According to the results from the surveys, the project crew and the context of the project were greatly $(91 \%)$ favored by the participants. They consider that the instructors as efficient $(90 \%)$. They expressed that they had taught the nature games and drama to their students they had learned during the training program.

Our approach was not minimalist with conceptual presentations because of aiming a knowledge level in order to establish terminal behavior, a behavioral improving in respect of Nature.

The fact that participants were able to notice the main components of the ecosystems at the end of the courses shows that nature training courses of IDE have created a considerably awareness concerning Nature

The factors which were effective over the decisions for participating were found as the learning about plants and animals in their habitats and sharing the experiences gained with their students as well as meeting nature lovers and scientists or accommodating in tents (special to IDE projects among which supported by TUBITAK)

The participants addressed that the NPA's as living laboratories and that they had supplied there great facilities for training their students. The model of the active learning method used in the projects was detected as affective on the awareness, perceptions, attitudes and behaviors of the participants towards Nature. 